\title{
Archaeological Testing Within the Southeast Corner of the Plaza at Mission Espada, San Antonio, Bexar County, Texas
}

Frances K. Meskill

Center for Archaeological Research

Follow this and additional works at: https://scholarworks.sfasu.edu/ita

Part of the American Material Culture Commons, Archaeological Anthropology Commons, Environmental Studies Commons, Other American Studies Commons, Other Arts and Humanities Commons, Other History of Art, Architecture, and Archaeology Commons, and the United States History Commons

Tell us how this article helped you.

This Article is brought to you for free and open access by the Center for Regional Heritage Research at SFA ScholarWorks. It has been accepted for inclusion in Index of Texas Archaeology: Open Access Gray Literature from the Lone Star State by an authorized editor of SFA ScholarWorks. For more information, please contact cdsscholarworks@sfasu.edu. 


\section{Archaeological Testing Within the Southeast Corner of the Plaza at Mission Espada, San Antonio, Bexar County, Texas}

\section{Creative Commons License}

\section{(c) (1) \&}

This work is licensed under a Creative Commons Attribution-NonCommercial 4.0 International License 


\section{ARCHAEOLOGICAL TESTING WITHIN THE SOUTHEAST CORNER OF THE PLAZA AT MISSION ESPADA SAN ANTONIO, BEXAR COUNTY, TEXAS}

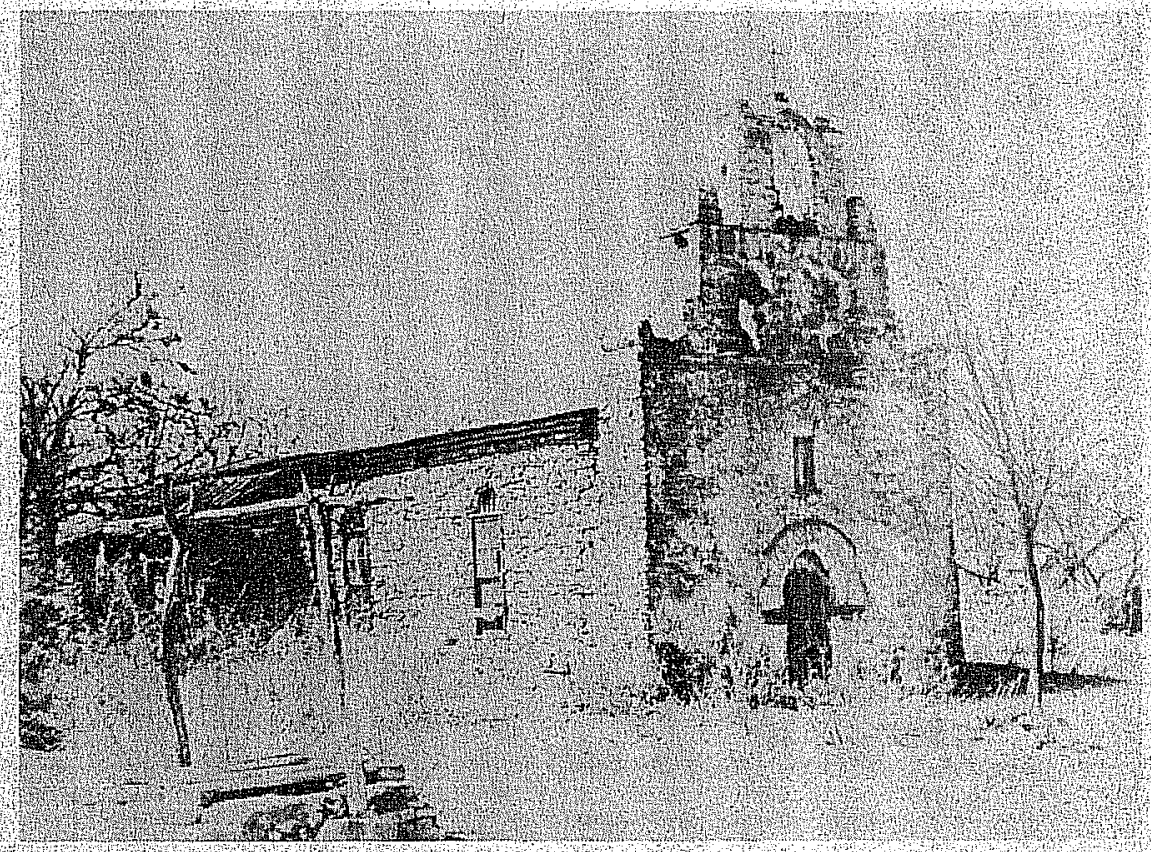

Frances K. Meskill

Center for Archaeological Research The University of Texas at San Antonio Archaeological Survey Report, No. 208 


\section{ARCHAEOLOGICAL TESTING WITHIN THE SOUTHEAST CORNER OF THE PLAZA AT MISSION ESPADA, SAN ANTONIO, BEXAR COUNTY, TEXAS}

Frances K. Meskill

Texas Antiquities Committee Permit No. 935

Center for Archaeological Research

The University of Texas at San Antonio ${ }^{8}$

Archaeological Survey Report, No. 208 
The following information is provided in accordance with the General Rules of Practice and Procedure, Chapter 41.11 (Investigative Reports), Texas Antiquities Committee:

1. Type of investigation: archaeological testing at Mission San Francisco de la Espada;

2. Project name: archaeological testing within the southeast corner of the Plaza at Mission Espada, San Antonio, Texas;

3. County: Bexar;

4. Principal investigator: Jack D. Eaton; field director: Anne A. Fox;

5. Name and location of sponsoring agency: Los Compadres de San Antonio Missions National Historical Park, San Antonio, Texas;

6. Texas Antiquities Committee Permit No. 935;

7. Published by the Center for Archaeological Research, The University of Texas at San Antonio, San Antonio, Texas 78249-0658, 1992.

A list of publications offered by the Center for Archaeological Research can be obtained by sending $\$ 1.00$ to the Center for Archaeological Research, The University of Texas at San Antonio, San Antonio, Texas 78249-0658. 


\begin{abstract}
In October 1990, pursuant to a contract with the National Park Service, the Center for Archaeological Research, The University of Texas at San Antonio, initiated test investigations in the southeast interior corner of the Mission Espada compound. The study focused on examining structural foundations and determining the depth of Mexican and Spanish colonial ground surfaces in the area.

Colonial period foundations were discovered under the south wall, as well as the probable original construction period surface and footing trench. Twentieth-century foundations were found in the unit excavated under the east wall. These likely continue south to the north wall of the room where the bastion is located.
\end{abstract}




\section{TABLE OF CONTENTS}

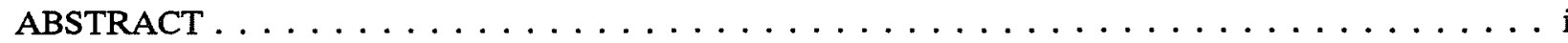
LIST OF FIGURES $\ldots \ldots \ldots \ldots \ldots \ldots \ldots \ldots \ldots \ldots \ldots \ldots \ldots \ldots \ldots \ldots$ iii

LIST OF TABLES $\ldots \ldots \ldots \ldots \ldots \ldots \ldots \ldots \ldots \ldots \ldots \ldots \ldots \ldots$ iii

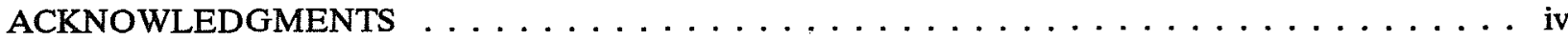

INTRODUCTION . . . . . . . . . . . . . . . . . . . . . . .

PREVIOUS INVESTIGATIONS AT THE MISSION $\ldots \ldots \ldots \ldots \ldots \ldots \ldots \ldots \ldots \ldots$

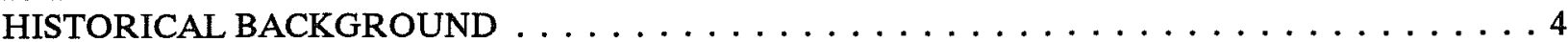

DESCRIPTION OF FIELD WORK $\ldots \ldots \ldots \ldots \ldots \ldots \ldots \ldots \ldots \ldots \ldots \ldots \ldots$

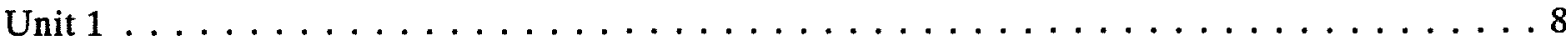

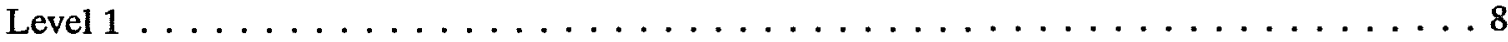

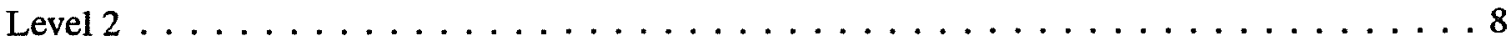

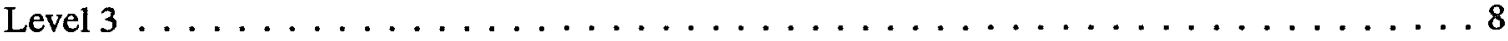

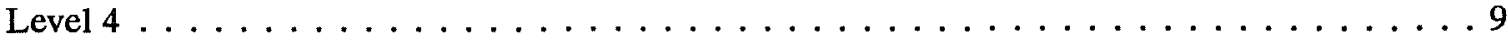

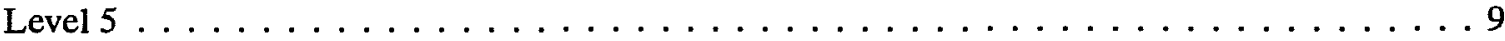

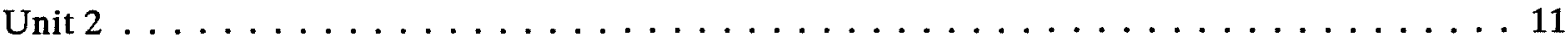

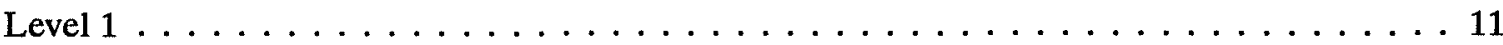

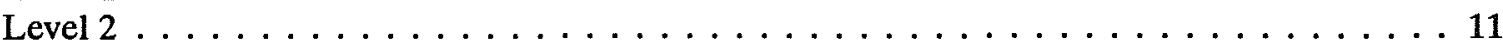

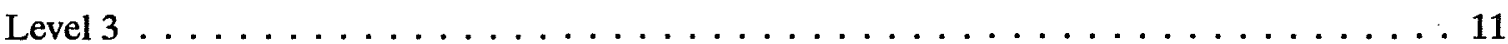

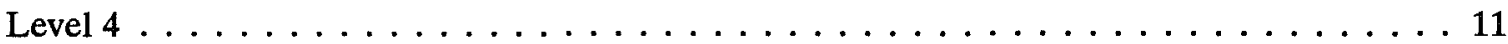

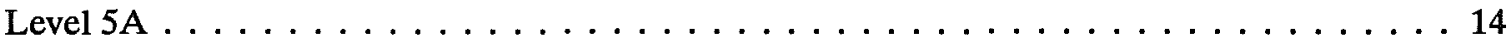

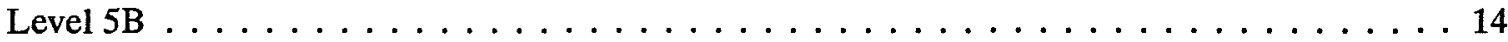

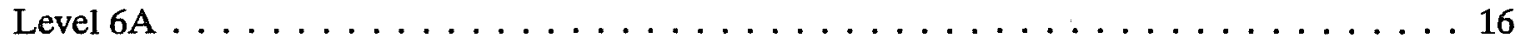

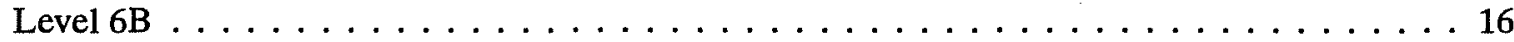

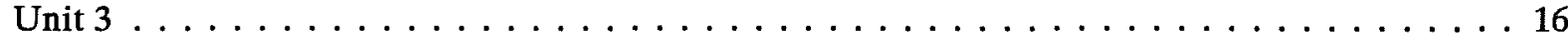

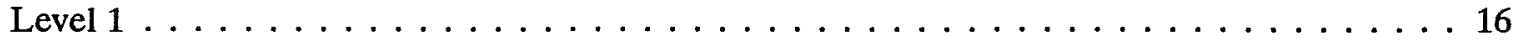

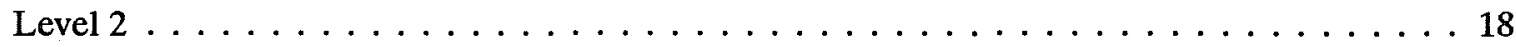

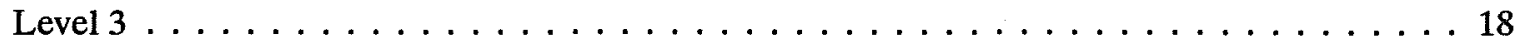

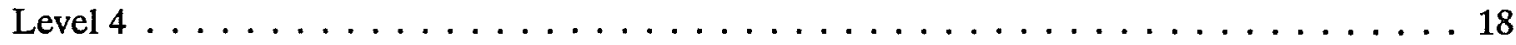

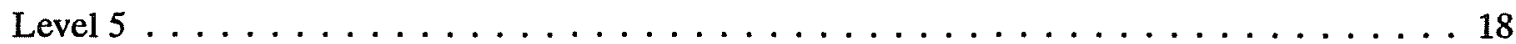

ARTIFACT ANALYSIS . . . . . . . . . . . . . . . . . . . . . 19

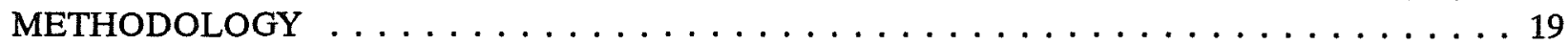

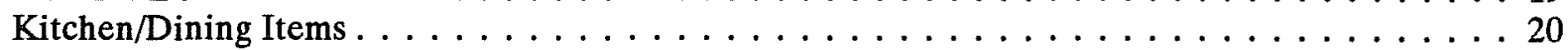

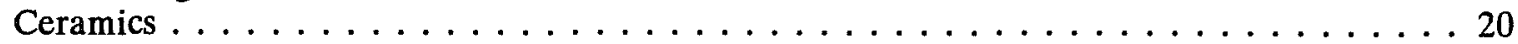

Group 1. Soft Paste Earthenwares - Unglazed . . . . . . . . . . . . . . . 20

Type 1. Primitive Fired Goliad Ware . . . . . . . . . . . . . . . . . 21

Type 2. Goliad Ware - Possibly Kiln Fired . . . . . . . . . . . . . . . . . 21

Type 3. Tonalá Ware - Kiln-Fired, Burnished Wares . . . . . . . . . . . . . 21

Type 4. Unglazed Bisque Ware . . . . . . . . . . . . . . . 23

Type 5. Other Unglazed Ware . . . . . . . . . . . . . . . . . 23

Group 2. Soft Paste Earthenwares - Glazed . . . . . . . . . . . . . . 23

Type 1. Lead Glazed . . . . . . . . . . . . . . . . . . . . . . 23

Sandy Paste Utility Ware . . . . . . . . . . . . . . . . . . . . 24

Fine-Textured Paste Wares . . . . . . . . . . . . . . . . . . 24

Type 2. Tin Glazed . . . . . . . . . . . . . . . . . . . . . . . . 24

Group 3. Hard Paste Earthenwares - Decorated Whitewares . . . . . . . . 25

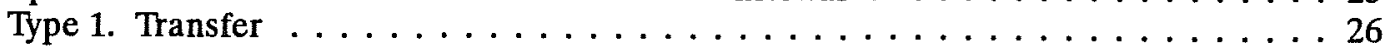

Type 2. Hand Painted . . . . . . . . . . . . . . . . . 26

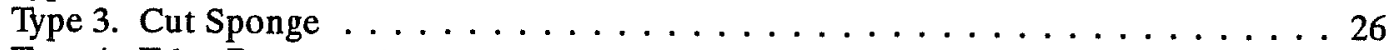

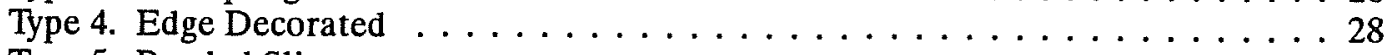

Type 5. Banded Slip . . . . . . . . . . . . . . . . . . . 28

Group 4. Hard Paste Earthenwares - Undecorated Whiteware . . . . . . . . 28

Group 5. Hard Paste Earthenwares - Creamware . . . . . . . . . . . . . 28

Group 6. Hard Paste Earthenwares - Yellowware . . . . . . . . . . . . 28

Group 7. Stoneware . . . . . . . . . . . . . . . . . . . . 29 
Group 8. Porcelain . . . . . . . . . . . . . . . . . . . . . . . . . . . 29

Glass Containers . . . . . . . . . . . . . . . . . . . . . . . . . . . . . . 29

Other Tableware/Kitchenware . . . . . . . . . . . . . . . . . . . . 29

Faunal Bone . . . . . . . . . . . . . . . . . . . . . . . . . . . 29

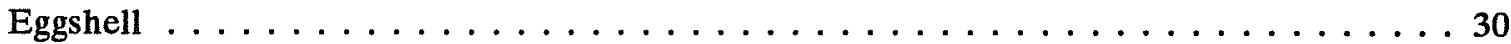

Mussel Shell . . . . . . . . . . . . . . . . . . . . . 30

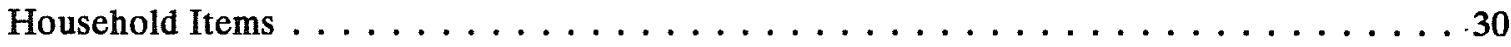

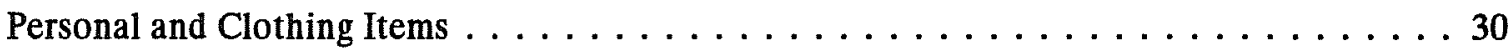

Modified Sandstone Disks . . . . . . . . . . . . . . . . . 31

Doll Parts . . . . . . . . . . . . . . . . . . . . . 31

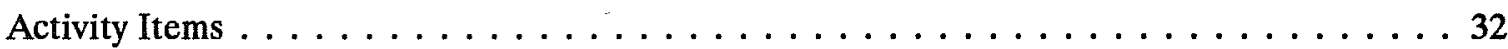

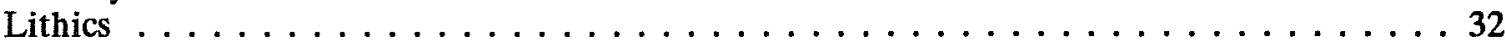

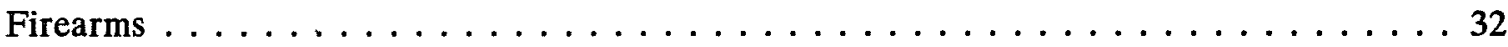

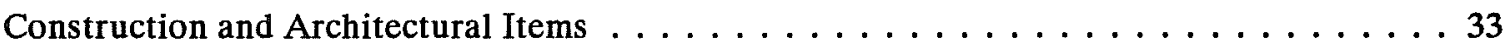

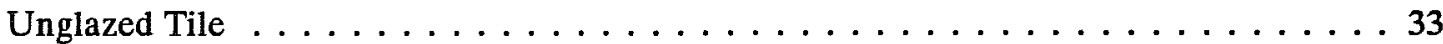

Marine Shell . . . . . . . . . . . . . . . . . . . . . 33

Utilities and Other Construction Related Items . . . . . . . . . . . . 33

Miscellaneous Items . . . . . . . . . . . . . . . . . . . . 34

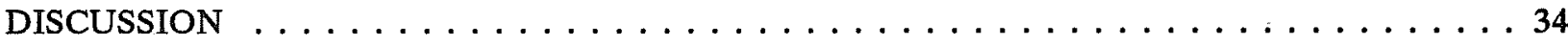

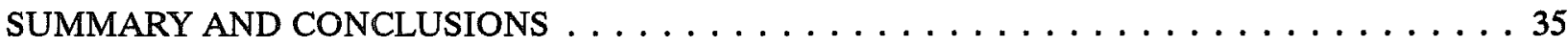

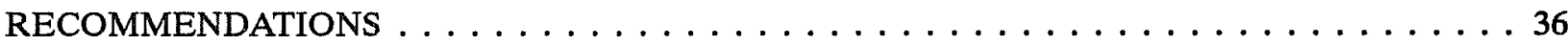

REFERENCES CITED . . . . . . . . . . . . . . . . . . . . . 37

\section{LIST OF FIGURES}

1. Location of Mission San Francisco de la Espada . . . . . . . . . . . . . . . 2

2. Interior Plaza at the Southeast Corner, 1930 s . . . . . . . . . . . . . . . . 3

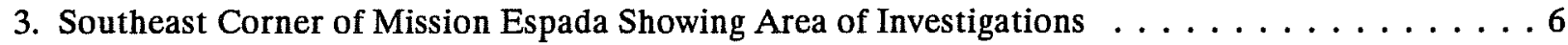

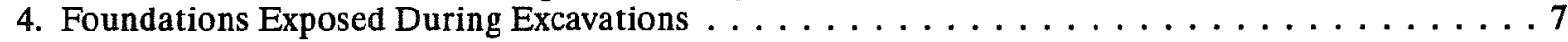

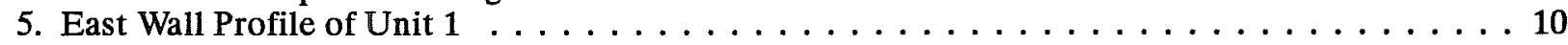

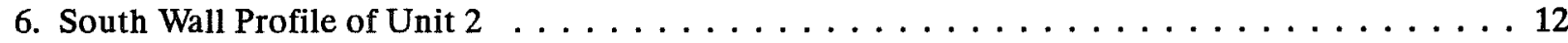

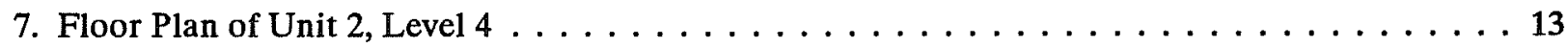

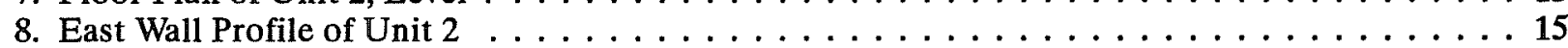

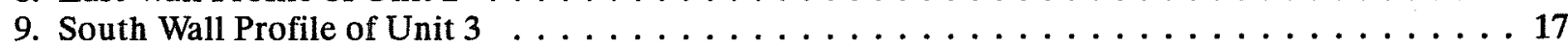

10. Sample of Artifacts Recovered . . . . . . . . . . . . . . . . . . 22

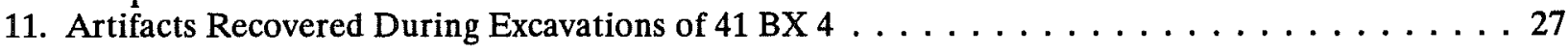

\section{LIST OF TABLES}

1. Artifacts from Mission Espada . . . . . . . . . . . . . . . . . . . . 19

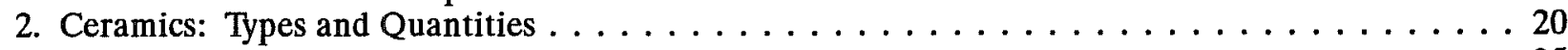

3. Ceramics: Types and Proveniences . . . . . . . . . . . . . . . . . . . . 25 


\section{ACKNOWLEDGMENTS}

The author wishes to gratefully acknowledge the invaluable advice and assistance of Anne A. Fox and the Los Compadres de San Antonio Missions National Historical Park (NPS), the organization which funded the project. Participating CAR-UTSA staff include Waynne Cox, Marty Krueger, Barbara Meissner, Willie Mendez, Shirley Mock, Jose Zapatá, and Frances Meskill. The talented and generous work by volunteers Darla Cox, Burnley Duke Smith, Don McEwan, Bridget Smart, Ann Garland, Maureen Brown, Clint McKenzie, and Kevin Gross was critical to the success of the excavations. Park rangers John McManess, Myron McCoy, and Jesse Rodriguez, were very helpful and accommodating to the crew, and the visits, comments, and/or assistance by NPS personnel Gary Miles, Hank Florence, Alan Cox, Robert Amdor, and James Ivey were greatly appreciated. Diane Ballinger made the faunal identifications, and Barbara Meissner made relevant observations on the materials. Sam Nesmith provided information on the firearms, and Tommy Tomesal assisted with other metal identifications. Minnie McRae, a student at the Espada school during the 1940s and a descendant of the de la Garza family, graciously provided historical information on the school at the southeast corner, while Southwest Enrichment Center students who visited the site enthusiastically assisted in recovering materials on the screen. In addition, Brother Edward Loch was most courteous and helpful during research in the Catholic Archives at San Antonio. 


\section{INTRODUCTION}

From October 22 to October 26, 1990, the Center for Archaeological Research (CAR), The University of Texas at San Antonio (UTSA), conducted archaeological testing at Mission San Francisco de la Espada (Fig. 1) in accordance with a National Park Service contract funded by Los Compadres de San Antonio Missions National Historical Park. Impending modifications by the National Park Service, necessitated by drainage problems in the area, prompted the investigations of the southeast corner of the mission compound's interior plaza (Fig. 2).

The purpose of the testing was to examine structural foundations and to determine the general depth of fill overlying the Mexican and Spanish colonial period surfaces. The three test units yielded a sequence of materials dating to Spanish colonial times. The investigations revealed that a 20 th-century foundation exists under the east wall of the plaza where a 1932 schoolhouse (the Centro) is located and that mission period foundations are no longer intact at this section of the wall. Original colonial foundations were found in place under the south wall.

Principal investigator for the project was Jack D. Eaton, acting director of the CAR; Anne A. Fox was co-principal investigator and project director, and Frances $\mathrm{K}$. Meskill served as field director. The research was done in compliance with Section 106 of the National Historic Preservation Act of 1966 and Executive Order 11593 and under the terms of Texas Antiquities Committee Permit No. 935. All field notes, photographs, and drawings pertaining to the project are on file at the CAR-UTSA.

\section{PREVIOUS INVESTIGATIONS AT THE MISSION}

A limited number of archaeological investigations have been conducted at Mission Espada, one of these occurred in the southeast section of the compound. During May 1976, archaeological excavations were focused on the exterior southeast corner of the wall, adjacent to the bastion (defensive tower) (Fox and Hester 1976). The archaeological work, occurring in conjunction with plans to stabilize and repair the tower, examined wall footings to determine their depth and method of construction. Foundations were found to extend down to $95 \mathrm{~cm}$ in Test Pits A and B (ibid.:12). Test Pit C was placed inside the tower against the interior wall, where footings continued to a depth of $85 \mathrm{~cm}$ (Fox and Hester 1976:22). Evidence found at the juncture of the exterior wall of the bastion and the south wall in Test Pit B suggests that the bastion may have been built independently of the compound wall construction at a later date.

During March 1977, the Texas Historical Commission (Killen and Scurlock n.d.) conducted excavations of two 18th-century lime kilns which lie north of the mission. The study recorded architectural data on the structures and the depth and contents of the deposits within. Colonial and post-colonial materials were collected during these investigations.

In 1981 work was undertaken in the vicinity of the church at Area A, north of an alignment which Harvey P. Smith, Sr., in identified WPA (Work Projects Administration) drawings as the cemetery wall (Fox 1981). Although the area (which was targeted as the site of a future parking lot) yielded a thin cultural deposit, no direct evidence was found to support the extension of the cemetery beyond the north wall, as Smith had recorded. A second section (Area B), the site of a mid-20th-century convent, was tested at the east wall of the mission compound. The tests conducted in this area concluded that few intact remnants of the structure were in place.

The National Park Service initiated investigations in 1984 to examine the rooms forming the southeast corner of the compound prior to the structures' stabilization and repair (Escobedo n.d.). The repair necessitated the exposure of interior foundations and removal of soil fill. The room north of the bastion was gridded and excavated, and a test unit was opened in the west room, the same room where a sewer pipe trench was exposed. A nicely fitted, thick sandstone floor was found in place within the west room, prompting further opening of the area. An alignment of stones was located below. Escobedo reported that the location of a threshing area with rock and flagstone floor mentioned in the 1772 inventory of 


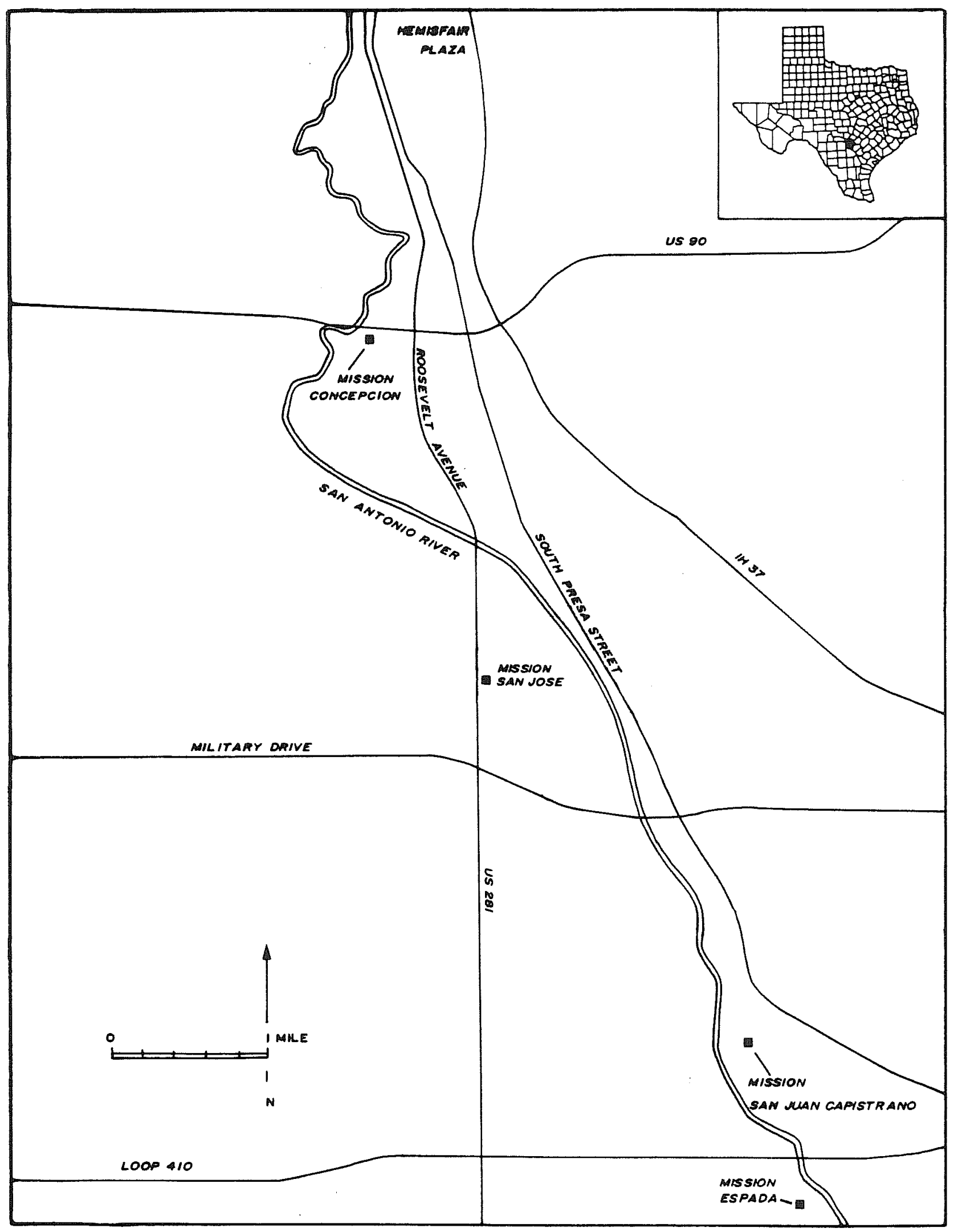

Figure 1. Location of Mission San Francisco de la Espada. 


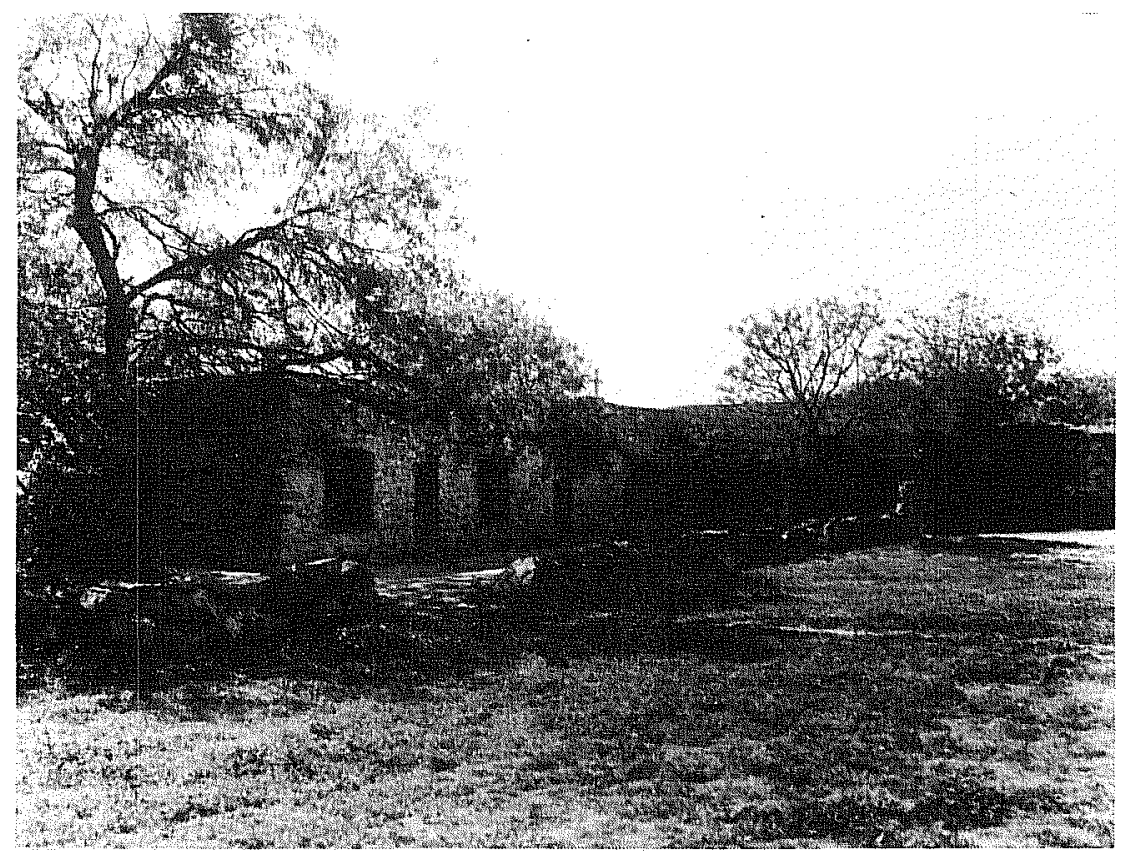

Figure 2. Interior Plaza at the Southeast Corner. From the Kreck collection, attributed to the 1930s. Courtesy of the Catholic Archives of the San Antonio Archdiocese. 
Mission Espada, had not been identified, suggesting the possibility that the heavy floor seen in the room west of the bastion could be a remnant of the threshing floor.

\section{HISTORICAL BACKGROUND}

The history of Mission Espada has been reviewed by a number of authors, and the reader is invited to read Habig (1968:192-233), Winfrey (1965:103-124), Castañeda (1937:23), Smith (1980a:3-18, 1980b:36-39), and the previously cited archaeological reports. The National Park Service Draft HSR (Historic Structures Report) prepared by Ivey, Thurber, and Escobedo (1990) relates a detailed composite of archival and historical information, particularly concerning structural data. A brief sketch of the history of the mission is recounted here.

Mission San Francisco de la Espada, the southernmost in the Alamo chain of missions, was founded along the banks of the San Antonio River in 1731. The mission had been relocated from its earlier location in east Texas when proselytization efforts failed there. The outlying position of Espada (Fig. 1) made it vulnerable to Indian attack.

The familiar Espada church facade was constructed by 1745, as the sacristy of a larger stone church which had been planned but was never completed (Ivey, Thurber, and Escobedo 1990:140). The sacristy served as the church for much of Espada's history, as it does today. The mission compound developed over time, with the southeast section (where the CAR investigations were undertaken) apparently being constructed in the final building phase (Smith 1980b:38).

Construction of the southeast corner may have been completed as early as 1762, as a report on the missions dating from this year mentions three rows of Indian stone houses (Porrua Turanzas 1961:259, as noted in Fox and Hester 1976: Habig 1968:213), which perhaps included the southeast plaza rooms. Ivey, Thurber, and Escobedo (1990:149) however, cogently argue that construction occurred in preparation for secularization ca. 1780. The defensive bastion at the outside corner appears to have been built after the compound rooms (Fox and Hester 1976:12). Although an inventory made when the Zacatecan Franciscans assumed control of the mission in $\mathbf{1 7 7 2}$ mentions a "castillo" with cannons, a structure that could suggest the bastion, Fox (personal communication) believes that the "castillo" actually refers to fortifications that were in place at the mission gate. The Spanish missionaries were charged with the directive of spreading the faith, but also served as agents of the Spanish crown. The Franciscans who came to the northern borderlands of Mexico carried with them the zeal to Christianize and civilize, using faith - occasionally backed by force - to spread and inculcate their message. The dynamic encounter between the old and the new worlds profoundly changed the lives not only of the native peoples, but probably of the friars themselves.

Leading the settled, disciplined life style of the missions, the Indians tended irrigated crops, including cotton (Castañeda 1937:23) and domesticated livestock (at Espada's Rancho de las Cabras near present-day Floresville; refer to Ivey and Fox 1981; Ivey 1983; Jones and Fox 1983; Taylor and Fox 1985; Fox 1989:259-267). Blacksmithing, weaving, carpentry, masonry, and perhaps pottery making were among the skills taught by the Spaniards. The numbers of neophytes, or Christianized Indians, residing at the missions fluctuated widely over the decades preceding secularization, when the Franciscans yielded their control. Bolton (1970:17) recounts that desertions were especially bad in 1737, when 137 neophytes (the entire number) fled Espada at one time; however, most were brought back by the priest and his military escort in the ensuing months (ibid.:17-18).

The bastion at the southeast corner is a relic of the defensive/protective purpose of the mission. It appears to be largely intact as originally built, and contains three cannon ports and seven musket ports. Records indicate that the function of the compound corner evolved greatly through time. Originally built as Indian quarters, it likely became the occupation site of soldiers during the 1820 s and early 1830 s (Ivey, Thurber, and Escobedo 1990:286). These troops might have been responsible for the construction of the bastion at 
the southeast corner (ibid.). In October 1835, Bowie and Fannin's army took over Espada from Mexican soldiers and repelled a subsequent attack by some 200 Mexican soldiers several days later.

Upon secularization, and prior to the Texans' fight for freedom, ownership of the rooms had been transferred to two parties: Jose Dolores Casanova, who acquired the north room, and Salvador Diaz, who became owner of the west room (Escobedo n.d.). The rooms changed hands through time (ibid.) and were reportedly sold to Rector Father Bouchu during his tenure at Espada (1875 to 1907).

Upon Father Bouchu's death, his property passed to his niece, an Incarnate Word sister, who lost her life in the St. John's Orphanage fire in 1912. The Incarnate Word congregation then assumed ownership (Brother Edward Loch, personal communication, 1991).

According to Park Ranger McCoy (personal communication), the present-day visitor contact station was used as a barbershop and neighborhood grocery store at one time. The 1932 school was added just north of the corner, and consisted of two dorms, two classrooms, and a hall (Catholic Archives). Minnie McRae (personal communication, 1991), a former student at the Espada school and a descendant of the de la Garza family, reports that the room west of the bastion functioned as kitchen and dining room for the school while the north room served as the sisters' quarters, the bastion itself serving as a tiny museum. At the time of the archdiocesan construction at the mission, the Diaz house functioned as the priests' residence during the 1950s, when water and sewer pipes were installed there (Escobedo n.d.).

An energetic priest, Father Bouchu, is credited with large-scale rebuilding of the Mission Espada compound in the late 1800s. WPA work in the 1930s was largely limited to architectural drawings and structural observations made by Harvey $\mathrm{P}$. Smith, Sr, with little actual reconstruction accomplished. In the 1950s and early 1960s, the Archdiocese of San Antonio rebuilt and capped off walls and foundations at the mission. Title to the mission was subsequently transferred to the National Park Service in 1981. The ancient Espada acequia water system is extant today, a living remnant of mission times; it is reportedly the oldest acequia still in use in the United States (Guerra 1982:30).

\section{DESCRIPTION OF FIELD WORK}

The scope and objectives of the CAR-UTSA investigations were clearly outlined in the testing request submitted by the National Park Service. The purpose of the testing was to examine structural foundations at the southeast corner of the plaza and to determine the depth of fill overlying both Spanish colonial and Mexican period surfaces.

Excavation was initiated by the CAR-UTSA crew October 22, 1990. Three test units were excavated during the operations (Fig. 3). Unit 1 was a 1- $\times 2-\mathrm{m}$ area situated against the east wall of the plaza; the southwest datum corner was set at $8 \mathrm{~m}$ north of the south wall of the plaza interior. Unit 2, approximately $178 \mathrm{~cm} \mathrm{x}$ $1 \mathrm{~m}$ in size, was located against the south wall of the compound (the north wall of the visitor contact station), with its southwest datum $3 \mathrm{~m}$ west of the interior plaza corner. The length of the unit was cut short by a flagstone walkway leading from an arched doorway at the east wall of the plaza. The long axes of Units 1 and 2 were placed perpendicular to the respective walls. Unit 3, a 1- x 1- $\mathrm{m}$ unit located away from the walls and onto the plaza floor, was situated with its southwest corner measuring $8 \mathrm{~m}$ from both the south and east walls of the plaza.

The units were excavated using the metric system, and all material was screened through $1 / 4$-inch hardware cloth. Vertical control was maintained using cultural or natural levels, or levels were dug in 10 -cm layers if that depth was reached before a stratigraphic change was noted. Cultural levels corresponded to the $10-\mathrm{cm}$ levels in several cases.

Excavations continued until sterile fill was reached in each of the units, a depth which occurred at about 43 to $45 \mathrm{~cm}$ except within disturbed or wall areas. At wall locations a deeper cut was made; the units were dug down to below existing foundations in order to expose the footings (Fig. 4a,b). Measurements for 


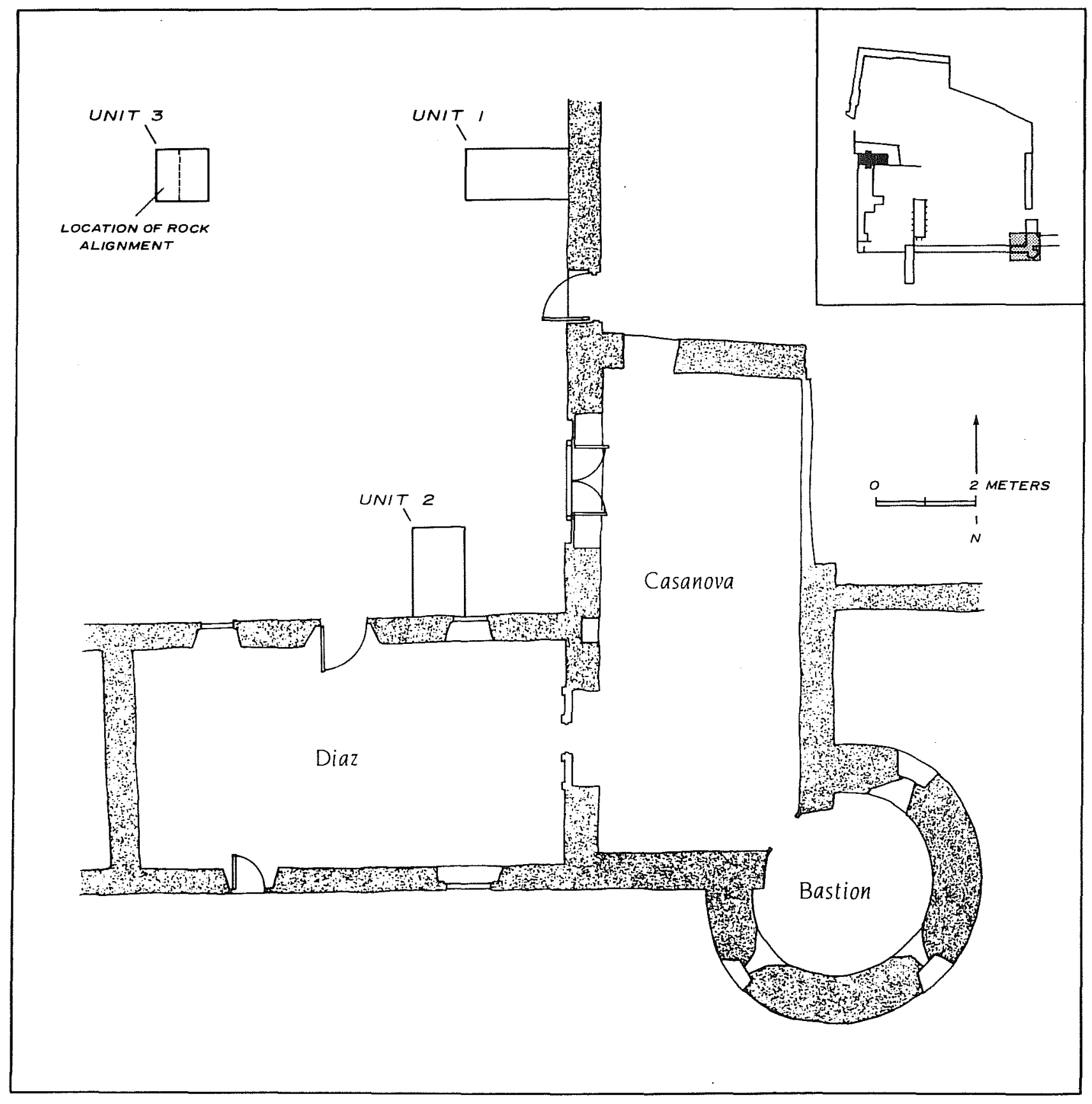

Figure 3. Southeast Corner of Mission Espada Showing Area of Investigations. The insert indicates location of test area within mission compound. 


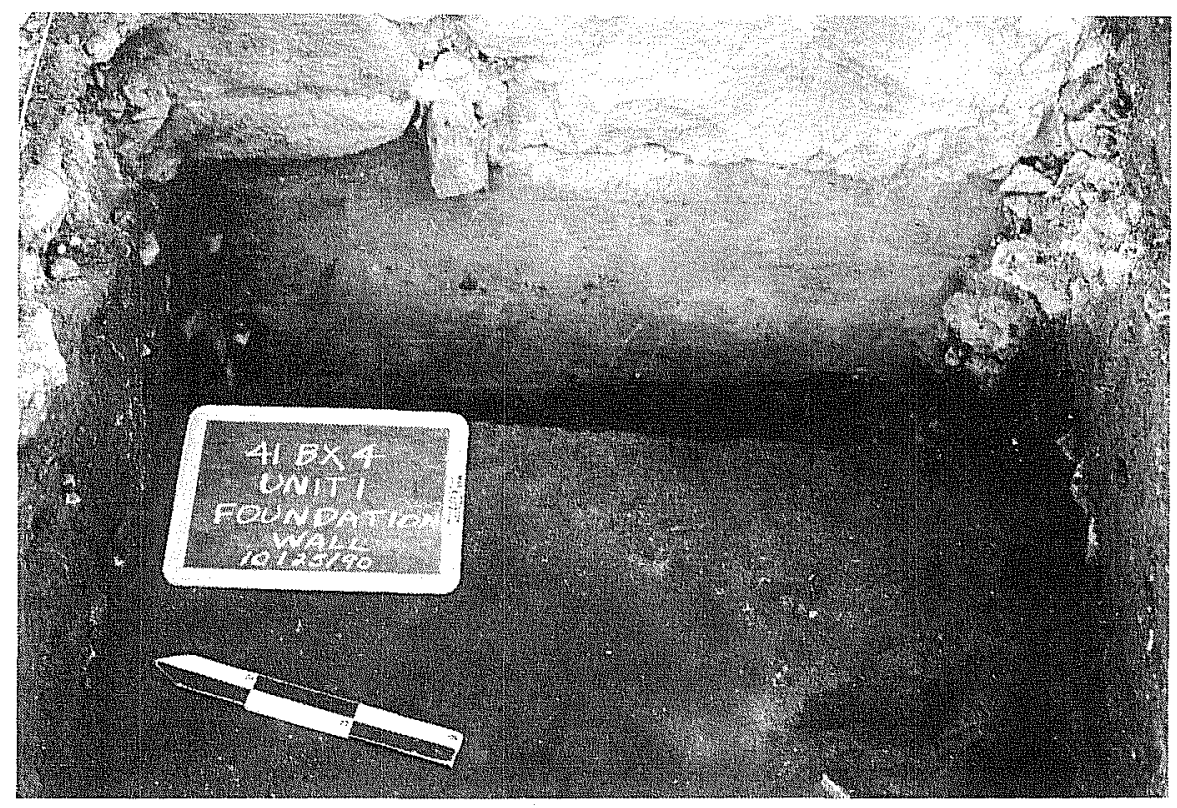

a

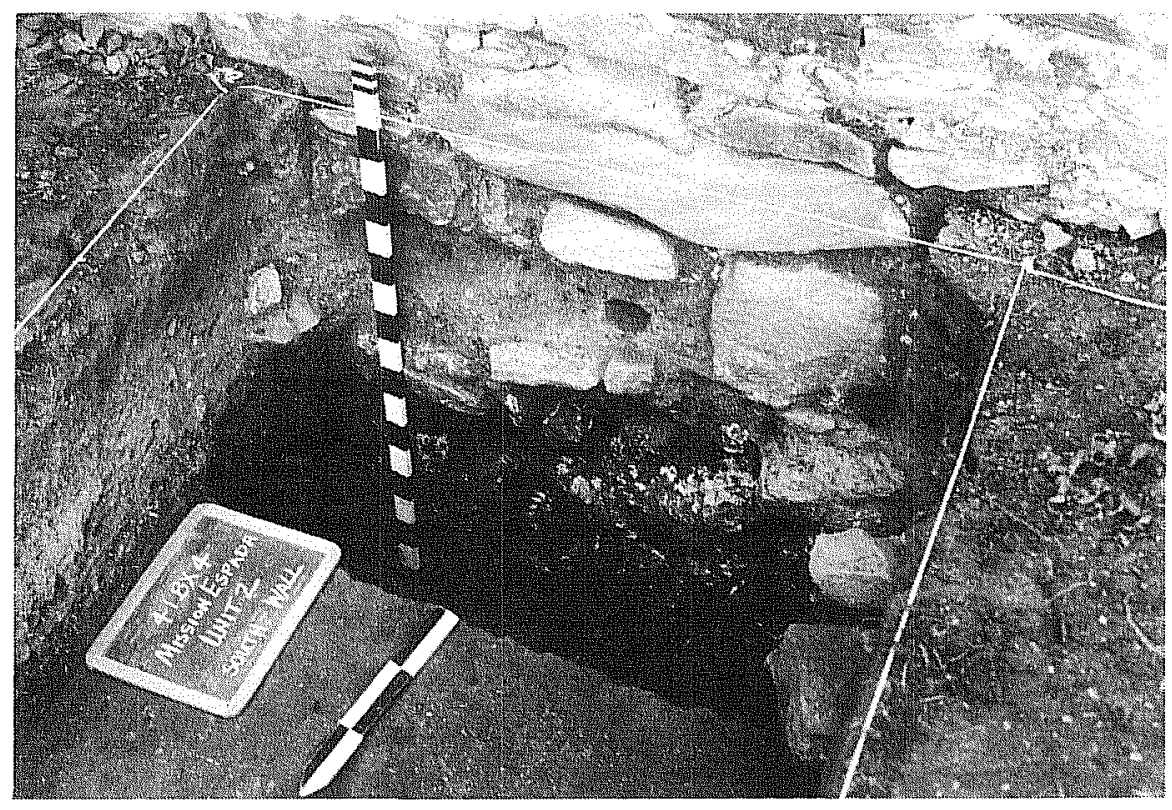

b

Figure 4. Foundations Exposed during Excavations. a, Unit 1, concrete foundations supporting the east wall; $b$, Unit 2, original mission period laid stone foundation beneath the south wall. 
depth were taken from the unit datum at the southwest corner. All walls were profiled, and plans of significant levels were plotted.

\section{UNIT 1}

Unit 1 was placed north of the old Centro schoolhouse doorway, which currently leads to the ranger office, senior citizen center, and visitor comfort station. The unit yielded a stratigraphic sequence dating largely from the school's construction in 1932 (with some contemporary materials found near the surface) to the Mexican and Spanish colonial periods. Some mixing was present due to root and animal intrusions and the rebuilding of the wall area during construction of the schoolhouse. Little evidence relating to mission period foundations in Unit 1 was found, although a poured concrete foundation wall associated with the 1932 schoolhouse was discovered. The concrete footing extended to a depth of approximately $90 \mathrm{~cm}$. Following the excavations, architects' structural plans documenting the specifications for the concrete foundation were found in the Catholic Archives at San Antonio. Three large rocks located below this concrete foundation are possible remnants of the mission period foundation.

\section{LEVEL 1}

In Level 1 a sandy, gravelly matrix was evident at the east wall, apparently resulting from the Centro schoolhouse construction. The remainder of the unit, however, had a consistently dark reddish brown (5 YR 3/4) soil, with some gravel present in the southwest quadrant. More recent artifacts (plastic, electric wire, wire nails, etc.) were excavated in this level in addition to late-19th-century undecorated whitewares, glass container fragments, tin scrap, and a number of other construction materials. At the terminus of the level, a flat sadiron (minus the handle) was exposed as well as a layer composed of numerous medium-sized (12 to $15 \mathrm{~cm}$ in length) and smaller ( 6 to $10 \mathrm{~cm}$ ) sandstone rocks. These rocks undoubtedly represent refuse from the school's 1932 construction.

\section{LEVEL 2}

Large voids, the result of animal burrowing, were apparent against the east wall beginning with Level 2 , which yielded late and early 19 th-century ceramic sherds (undecorated whiteware, spongeware, banded slipware, edge-decorated ware, and hand-pained earthenware), a porcelain doll arm, and a ceramic fragment that appears to represent a fragment of doll's hair. A primitive fired Goliad sherd, a piece of lead-glazed Mexican Galera ware, several bisque sherds (perhaps fragments of a figurine or doll), a small number of bone fragments, and several personal artifacts are attributed to this level. Some of the materials evidenced burning.

\section{LEVEL 3}

Artifact density increased significantly with Level 3, and the number of decorated whitewares (generally pre-dating the undecorated) became more frequent. As Level 3 was excavated two large sandstone rocks against the east wall were left in place; cement mortar was extant atop two of the three rocks exposed at this level. Decorated whitewares, typical of San Antonio area assemblages attributed to early-and mid-19th century, increased in number; transferware, hand-painted ware, spongeware, and edgewares were recovered. Goliad and lead-glazed wares were also present. Of particular interest from this level are two modified sandstone disks that are somewhat hexagonal in shape; similar artifacts yielded at Spanish colonial sites are identified in the literature as gaming pieces (see Artifact Analysis section).

Other artifacts of interest recovered in Level 3 include a medial section of a dart point, a brass thimble, and a doll's leg that represents another segment of the same toy found in Unit 1, Level 2. Glass container fragments from this level, which number 191, include one molded, patterned piece. A metal foot from a 
table service item, lead from lead pencils, hooks, seven buttons (six porcelain, one bone), and 178 fragments of bone were also recovered. Charcoal was present in the upper reaches of the unit, and a burrow disturbance was discovered in the central area of the layer (in the vicinity of the north wall).

\section{LEVEL 4}

Artifact frequency decreased in Level 4, although an extraordinary find was made - a small "musket ball," or pistol shot with a flattened area of impact. Habig (1968:224-225) reports that the Texan army, led by Fannin and Bowie, and consisting of 100 soldiers, made Mission Espada their headquarters after the few Mexican soldiers stationed there had fled. Several days after their arrival, the Texans repelled an attack of some 200 Mexican soldiers. It is possible that the shot represents remains of this encounter.

Also discovered at Level 4 was a lead seal with remains of wire attached on two sides, a type which was used during Spanish colonial times for the handling and shipping of wire-wrapped items (I. Waynne Cox, personal communication). Although ceramics decreased in number in Level 4, pottery diagnostics of Spanish colonial and Mexican periods increased significantly. Lead-glazed and primitive-fired Goliad wares predominated, although eight sherds of whiteware were present, including a banded green slipware with impressed designed and brown band; the presence of the whitewares may be attributed to intrusive burrowing in the central area of the unit and the disturbance associated with the east wall. Level 4 also yielded four chert specimens, including two "potlids" (ovular, concave pieces of chert that pop off when severely heated) and another heavily reddened and burned lithic piece.

The major component in this level was bone, much of which is large, and apparently cow bone. The bone has not been cut with a saw, but appears to have been cut with a cleaver-like instrument. Other dietary evidence taken from Level 4 includes mussel and eggshell. A probable fabric sample, brick tile fragments (appearing to be the same as those now seen in the facade of Espada church), and a brown machine-made glass container base were also found; the presence of this later glass artifact, probably post-1903 in date (when the fully automated bottle machine was patented [Lorraine 1968:43]), is apparently the product of the intrusion associated with construction at the wall.

\section{LEVEL 5}

Level 5, a 10-cm layer ( 40 to $50 \mathrm{~cm}$ ) in the western $175 \mathrm{~cm}$ of Unit 1, was excavated to sterile soil. A depth of $43 \mathrm{~cm}$ was measured at the location of the deepest artifact recovered in Unit 1, excluding one piece of charcoal found at $45 \mathrm{~cm}$.

Artifacts include four small glass fragments, two square nail fragments, two pieces of chert, a sherd of slipped Indian ware, a piece of lead-glazed Mexican pottery, and three hand-painted whiteware sherds. Bone decreased in quantity from Level 4, and much of it evidenced burning. In addition, two small glass sherds and one piece of whiteware were recovered. The $25 \mathrm{~cm}$ area adjacent to the east wall of Level 5 was collected separately due to the disturbance associated with the wall reconstruction and the deep burrows extant at that location. The vertical concrete foundation wall was exposed during the excavation of Level 5 (Fig.5). The concrete foundation wall continued as the remainder of the $25-\mathrm{cm}$ section adjacent to the wall was excavated to a depth of $95 \mathrm{~cm}$. The trench was almost devoid of artifactual material until the lower reaches (below $70 \mathrm{~cm}$ ) exposed one edgeware sherd and a number of plastic bags (ice, sandwich, bread) apparently cached by the animals associated with the large burrows against the wall. Three limestone rocks were discovered at about $84 \mathrm{~cm}$ below the foundation; the base of the stones lie at a depth of approximately $90 \mathrm{~cm}$. These rocks are possible remnants of the Spanish colonial foundation. 


\section{UNIT 1}

EAST WALL PROFILE

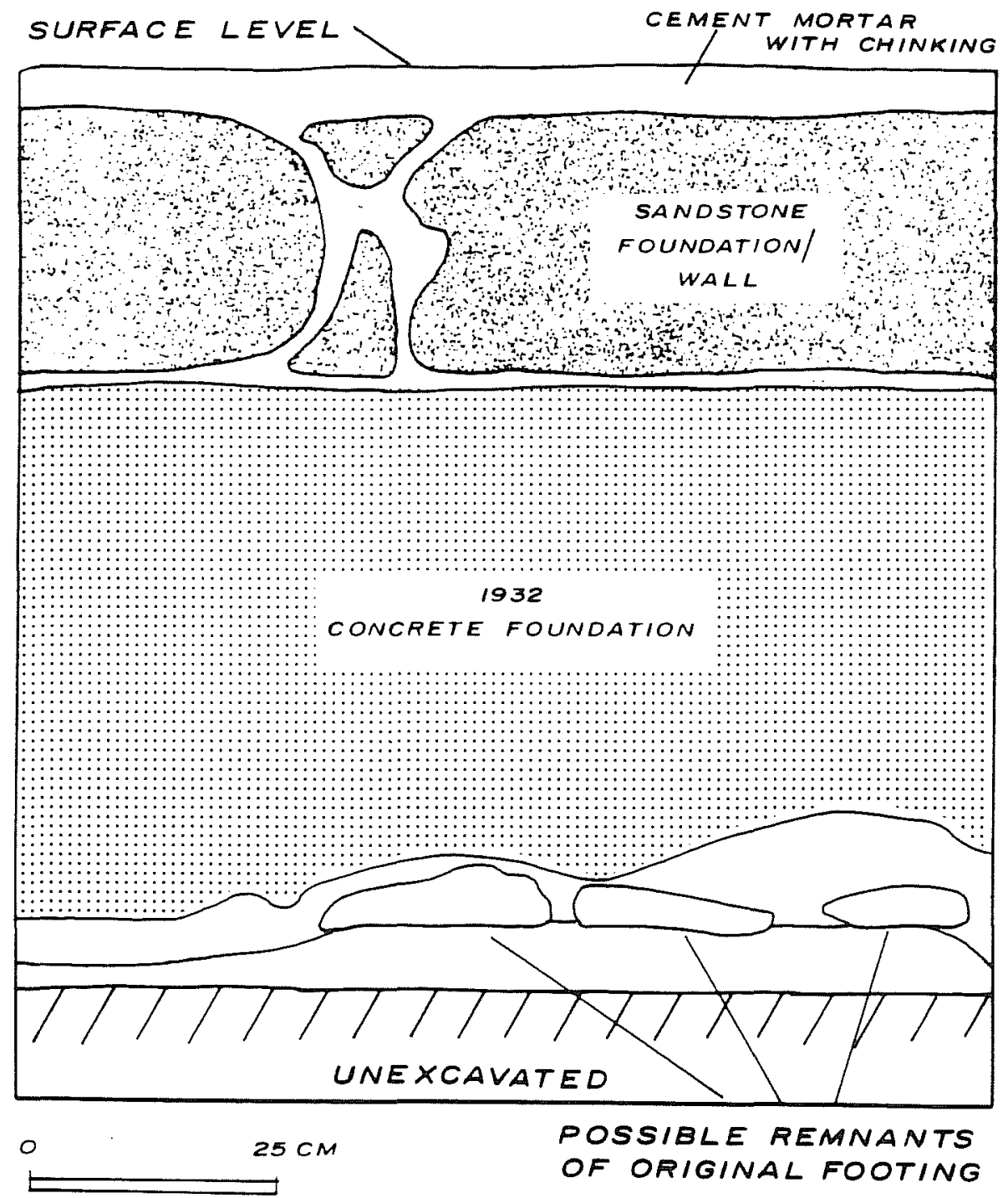

Figure 5. East Wall Profile of Unit 1. 


\section{UNIT 2}

Unit 2, approximately $178 \mathrm{~cm} \mathrm{x} 1 \mathrm{~m}$ with the long axis running north to south, was perpendicular to the north wall of the visitor center. Excavations were conducted at Unit 2 to a sterile layer (without artifacts) at $48 \mathrm{~cm}$ except for the $35 \mathrm{~cm}$ at the north end of the pit adjacent to the wall; there excavations proceeded below the Spanish colonial foundations $(90 \mathrm{~cm}$ ), which were discovered to be in place (Fig. 6).

\section{LEVEL 1}

An east-west alignment consisting of brick/tile fragments and sandstone, located some $125 \mathrm{~cm}$ north of the rock wall of the compound, was exposed within Level 1. To the north of this feature, which apparently represents a walkway/garden border, pea-sized gravels were seen beginning around the Level 1 floor. These are probable remnants of gravels utilized to surface the walkway, as similar, though larger, gravels are currently used to surface the back entrance to the senior citizen center. Few artifacts were collected from this area. South of the alignment was a dark brown loamy matrix; the floor of the level terminated with the finding of two large saw-cut, one-inch-thick plywood boards. Excavation in Level 1 yielded one sherd of Goliad ware, one sherd of banded slipware, three sherds of undecorated whiteware, four chert specimens, a World War II "ruptured duck" lapel insignia, and other artifacts representative of a broad time span.

\section{LEVEL 2}

The pea gravels exposed north of the alignment in Level 1 continued some 2 to $3 \mathrm{~cm}$ into Level 2 . A mix of 19 th-century and 20th-century materials was collected south of this feature, and included contemporary construction-related materials. Also found was a cockleshell resembling that seen on the cross sitting atop the old schoolhouse roof in the excavation area. A number of such shells were used as decorative elements in the cross, and the specimen recovered in Unit 2 could well represent one of its missing ornaments. Level 2 terminated at the base of the brick/tile and rock alignment.

\section{LEVEL 3}

Of particular interest in Level 3 was a copper percussion cap found on the screen. This type of item first came into the United States between 1815 and 1820 (see Artifact Analysis section). Also recovered were a very thin, cylindrical, cobalt-blue bead fragment, slate fragments, a whistle from a toy, and numerous ceramics, including two majolica sherds: San Diego Polychrome sherd, recovered at the floor of the level, and one undecorated white sherd. Other recovered ceramics include Goliad and lead-glazed wares, and decorated (hand-painted, banded slip, cut sponge, transfer), and undecorated whitewares, including one repoussé sherd.

The quantity of artifactual material, with the exception of construction items, increased noticeably in Level 3. Bone was present in some quantity, and charcoal was frequent. A nicely faced limestone rock was exposed in the wall, and individual patches of both cement and sand mortar could be observed immediately above the rock. Above the floor of Level 3, at a depth of approximately $26 \mathrm{~cm}$, were exposed several large sandstone rocks and an unusually large, fractured, brick/tile (or ladrillo) that measured approximately 25 $\mathrm{cm} \times 20 \mathrm{~cm} \times 4.3 \mathrm{~cm}$, its color slightly lighter and pinker than $7.5 \mathrm{YR} 6 / 4$ (light brown). The sandstones and brick tile were pedestaled in place.

\section{LEVEL 4}

Level 4, excavated to $37 \mathrm{~cm}$ (Fig. 7), exposed the base of the large flagstones first exposed in Level 3. Charcoal was present throughout the level and was particularly prominent in the southeast section of the unit. The stratum contained much bone, including an articulated cloven-hoofed leg segment of a goat or 


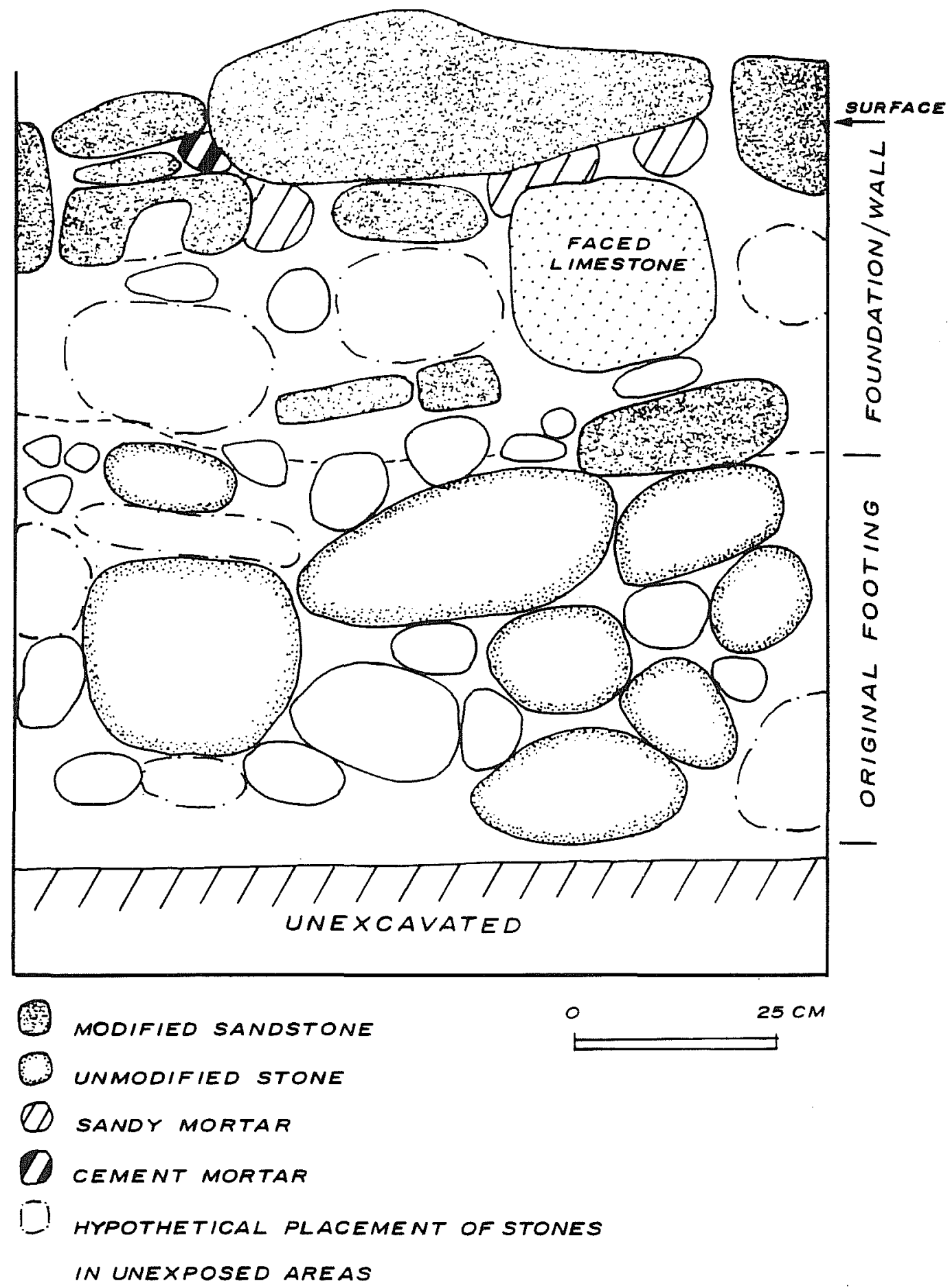

Figure 6. South Wall of Unit 2. 


\section{UNIT 2}

LEVEL 4 FLOOR PLAN

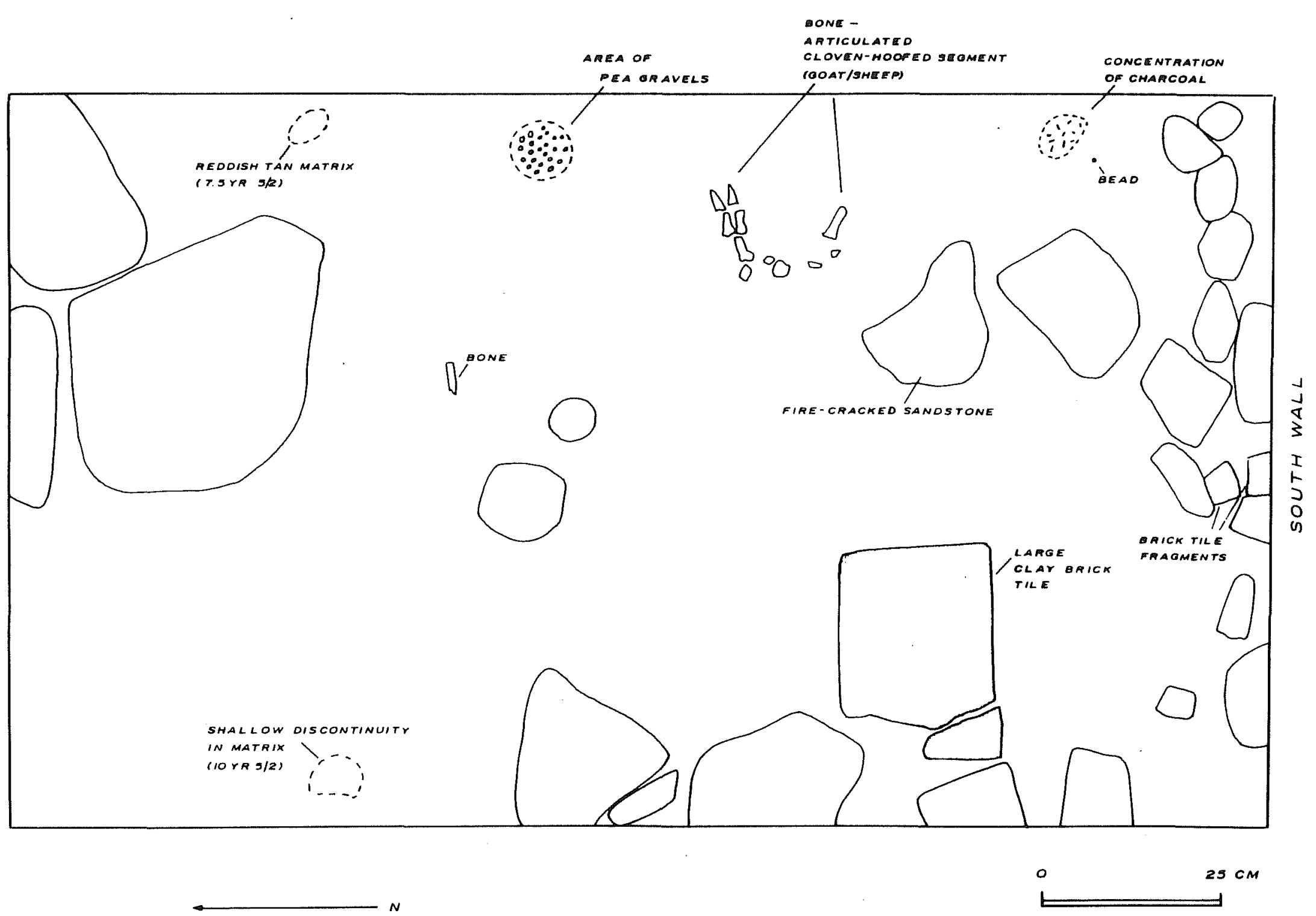

Figure 7. Floor Plan of Unit 2, Level 4. 
sheep near the east wall in the southern section of the unit. A large fire-cracked sandstone located in the vicinity of the bone suggests the likelihood that the area was used for cooking, while 144 items collected within Level 4 indicates that it also served as a locus where bone was discarded.

A small turquoise-colored seed/embroidery bead was also discovered in the southeast quadrant on the floor of this stratum. Additional sandstone rocks were exposed as the layer was dug, and discontinuities in color were recorded along both the east and west walls of the unit about $130 \mathrm{~cm}$ north of the unit datum. Although the regularity of placement would suggest the possibility of postholes, the areas at the west wall were quite shallow and ephemeral. The area at the east wall appeared to be associated with the burrow shown below it in the east wall profile (Fig. 8).

Ceramics recovered in Level 4 include three majolica sherds: a San Diego sherd of the Aranama Polychrome tradition, dating from 1790 to 1830 (Barnes 1972: 12; May 1972:36); another probable San Diego sherd; and a San Elizario Polychrome specimen, dated from about 1750 to 1800 (May 1972:23). Also collected were twenty Goliad sherds and 12 lead-glazed specimens. A modified, painted whiteware sherd disk, which may be a gaming piece, was also recovered along with six undecorated whitewares, one creamware sherd, four other decorated whiteware specimens, and a number of copper and lead pieces. Also recovered at Level 4 was an Alamo Brand overalls button, and although no date has yet been determined for the item, it is stylistically attributable to the late 19 th century. In addition, concrete was collected at the wall zone.

The southern boundary of this unit is the wall of the present-day visitor contact station, within which Escobedo had discovered a heavy, well-fitted flagstone floor dug in the 1984 excavation. Based on its workmanship, he designated the floor as Spanish colonial and suggested that it might be associated with remains of an unidentified threshing area as recorded in the 1772 inventory. The relatively small difference in elevation does not, however, discount the Unit 2 stones being part of the same floor. Measurements were made from the top of this flagstone floor level to compare its depth to that of the stones found at the north section of Levels 3 and 4 of Unit 2 to determine if these might be extensions of the floor. The visitor contact station stones were found to be at a somewhat higher level, some $10 \mathrm{~cm}$ above the sandstones found in Unit 2.

Escobedo (n.d) reports that Jack Eaton, noting that the heaviness of the floor was suggestive of a specific function, proposed that its weight was suitable for cannon-bearing. The flagstones found in the CAR-UTSA investigations within the compound, if in situ, could then be remains of a plaza floor slightly lower than that of the room.

\section{LEVEL 5A}

Excavation of Level 5A began at the base level of the large sandstones removed from the Level 4 for ( 37 $\mathrm{cm}$ depth). As excavations began near the south wall of the unit, a change was noted; a matrix mottled with white flecks (possibly limestone) appeared about $1 \mathrm{~cm}$ down. This matrix was compacted, lighter in color, and contained little or no charcoal when compared to the loose, dark gray brown soil overlying it. Level 5A was then excavated across the unit to expose this new stratum. The layer overlying the mottled surface was quite shallow (1 to $3 \mathrm{~cm}$ in depth) through much of the unit, except for a deeper, burrowed area discovered in the northwest quadrant. Goliad and other unglazed wares and San Diego majolica shered were found in Level 5A, with no European wares collected. A rectangular ground sandstone artifact from this stratum appears to be a sharpening stone. The level is dated to the late Spanish colonial period (post-1760), and the cultural debris collected here may represent remnants of the early occupation of the corner rooms by mission Indians.

\section{LEVEL 5B}

The compacted mottled matrix found at $38 \mathrm{~cm}$ was excavated to $48 \mathrm{~cm}$ and collected separately as Level $5 \mathrm{~B}$; artifacts were recovered to a depth of about $43 \mathrm{~cm}$. The surface of this level appeared to be related to 


\section{UNIT 2}

EAST WALL PROFILE

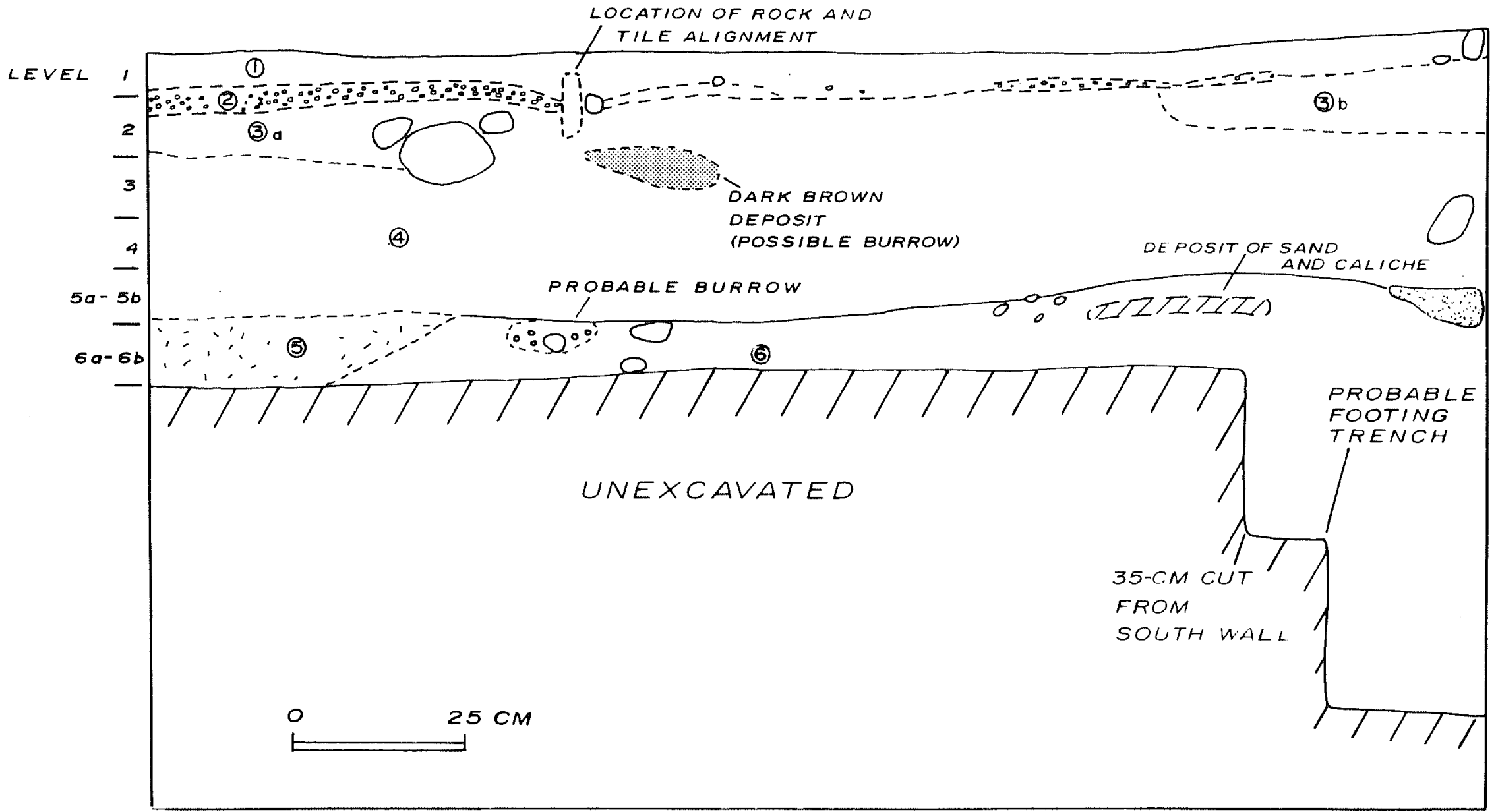

Figure 8. East Wall Profile of Unit 2.

1 light brown sandy fill (10 YR 6/2)

2 light brownish gray (10 YR 6/2) matrix with pea size gravel

3a compacted brownish gray (10 YR 6/2) sandy fill, grading to slightly darker at contact with level 4

$3 \mathrm{~b}$ compacted matrix slightly lighter in color than $3 \mathrm{a}$

4 gray (10 YR 6/1-6/2) loose matrix containing charcoal and bone

5 area of rodent burrows, loose brownish gray (10 YR 5/1) containing much charcoal

6 grayish brown (10 YR 5/2) fill, very little cultural material. 
construction of the wall foundations (see east and south wall profiles, Figs. 6 and 8). The materials collected in the upper regions of the level likely predate the building of the southeast corner of the plaza except for the area immediately against the wall foundation (note the sand and caliche deposit in the east profile near the south wall). Level 5B appears to date to be between the mission's founding in 1731 and the phase of mission building in this corner between 1762 (Habig 1968:212-214) and the 1780s (Ivey, Thurber, and Escobedo 1990:149).

A modified flake or blade fragment and two other chert specimens were located in the upper reaches of Level 5B, as well as four lead-glazed sherds, brick/tile fragments, plaster, cement (from the wall construction area), faunal bone, and mussel shell, including a possibly modified diamond-shaped piece. In addition, three Tonala sherds, the only such specimens from the excavation, are attributed to this early level.

\section{LEVEL 6A}

The lower reaches of the rodent burrow were excavated as Level $6 \mathrm{~A}$. Only bits of charcoal and a bifacing flake fragment were collected in this level.

\section{LEVEL 6B}

A $35-\mathrm{cm}$ section adjacent to the south wall was dug, and materials collected from the section were bagged separately. This level, designated as Level $6 \mathrm{~B}$, began at $48 \mathrm{~cm}$ in order to determine the depth of the wall footings. Recovered were six Goliad sherds having much bone temper (at least three from the same vessel), six lead-glazed sherds, a small amount of bone, and some brick/tile fragments. Level 6B appears to date from the Spanish colonial construction period except for a faced limestone rock in the top few centimeters of the south wall profile which suggests a later episode of rebuilding.

A somewhat subtle change in the matrix was detected $20 \mathrm{~cm}$ north of the wall at about $68 \mathrm{~cm}$. The soil within the $20 \mathrm{~cm}$ fronting the wall contained white flecks and was slightly lighter in color, this almost certainly representing the trench dug for the original wall foundations. Excavations continued an additional $20 \mathrm{~cm}$ to the base of the unit.

The Spanish colonial foundation, composed of unmodified rock, was found to be in place as the wall area was cleared away. The exposed rocks varied considerably in size; the large stones measured 25 to $40 \mathrm{~cm}$ in length, while smaller rocks ranged in size from 5 to $12 \mathrm{~cm}$. The wall footing began at a depth of about 45 $\mathrm{cm}$ and continued to $89 \mathrm{~cm}$. The unit was excavated to $94 \mathrm{~cm}$, where a change of soil indicated the probable base of the wall trench.

\section{UNIT 3}

Unit 3 was a 1- $\mathrm{x} 1-\mathrm{m}$ unit with its southwest corner situated $8 \mathrm{~m}$ from both the east and south walls of the plaza. The unit was excavated to sterile earth (Fig. 9).

\section{LEVEL 1}

Caliche gravels were found below the humic layer in Unit 3, Level 1. Artifactual material was very low in quantity, but included a tooth from a small ungulate (hoofed animal), such as a mature goat or sheep. 
UNIT 3

SOUTH WALL PROFILE

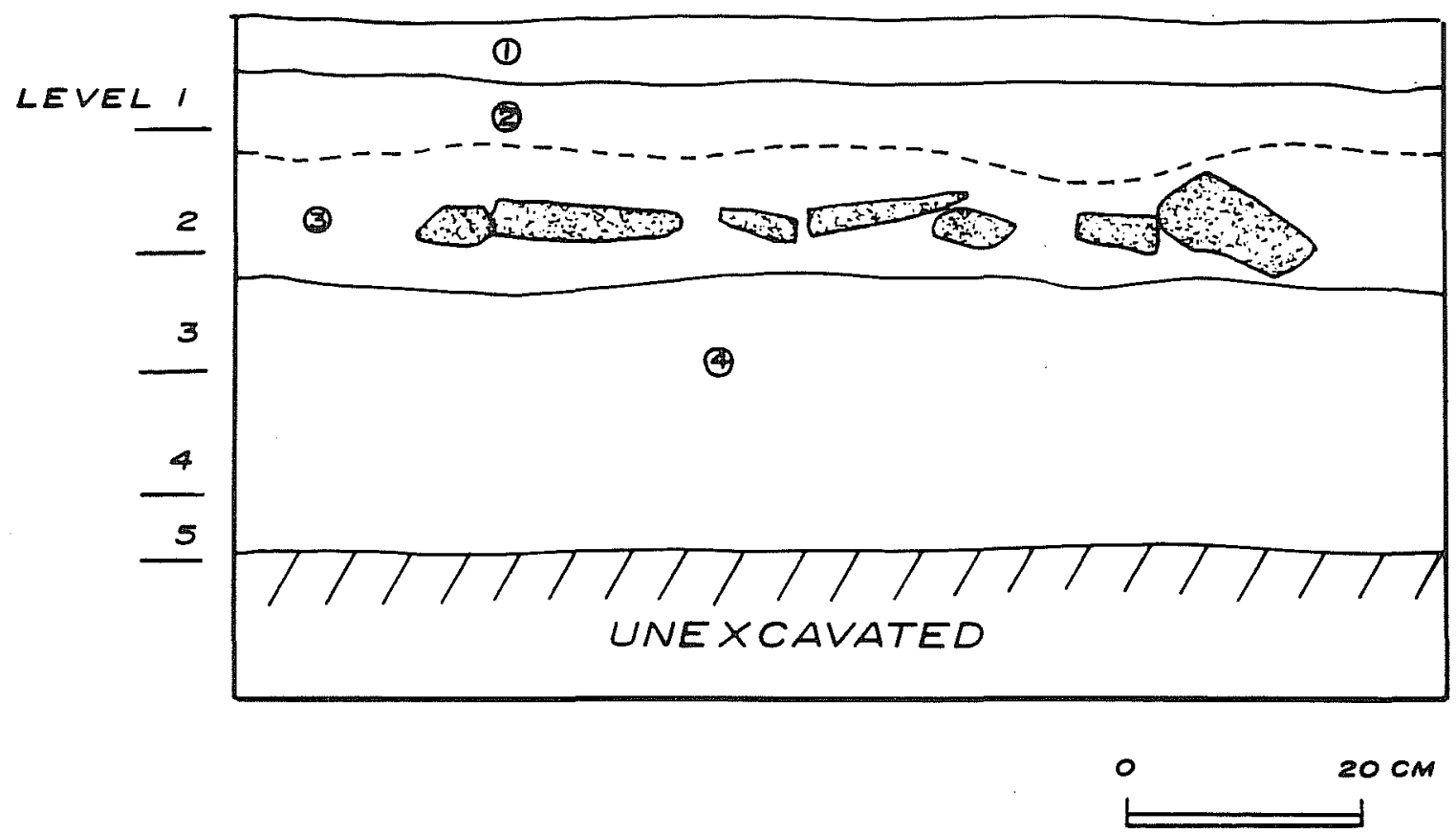

Figure 9. South Wall Profile of Unit 3.

1 dark grayish brown (10 YR 4/2) loam

2 light brownish gray (10 YR 6/2) loam with some gravel

3 light colored (10 YR 8/1) clayey deposit containing a ground stone mortar

4 dark grayish brown (10 YR 4/2) loamy clay containing charcoal, bone fragments, and ceramic sherds. 


\section{LEVEL 2}

At Level 2, a north-south rock alignment occurred along the western half of Unit 3. Patches of lime mortar were extant at this loose, fairly shallow rock feature; rock scatter was present in the remainder of the unit.

A concentration of artifacts consisting of square nails, metal scrap, a bottle cap, and a very small piece of window glass was located at the center of the unit within a dark charcoal-filled soil. A minimal amount of material was collected outside of these two features; these included a single whiteware sherd, cement bits, a piece of roofing material, a pencil eraser, and wire and square nails. Except for the nail count, Level 2 yielded only a small amount of artifactual material.

The deposit's ephemeral nature was somewhat problematic until later research at the Catholic Archives in San Antonio revealed a photograph, taken after the 1932 school construction, which records a low-lying rock wall parallel to the east wall of the compound and some $8 \mathrm{~m}$ onto the plaza (Fig. 2). The rock found in Unit 3 very likely represents remains of that low-lying wall. Artifacts from the rock area in Level 3 consisted largely of brown glass fragments, although both decorated and plain whiteware (including a probable figurine base), clear and aqua glass, and metal scrap were also recovered.

\section{LEVEL 3}

Similar artifacts (whiteware, brown glass) and construction materials (roofing tar and felt, a number of wire nails, and concrete) were found in the remainder of Level 3 . One of the decorated whiteware sherds is a nicely printed specimen of red transfer ware. The decorated whitewares occurred at a depth of 26 to $30 \mathrm{~cm}$, where a porcelain and a stoneware sherd were also found. In addition, cockleshell (similar to that associated with the schoolhouse cross), mussel shell, and bone were collected.

\section{LEVEL 4}

Artifact density decreased in Level 4 of Unit 3, although the incidence of bone increased. Of the 13 unslipped bone-tempered redwares found here, several evidenced the markedly even firing associated with a kiln, suggesting the possibility that kiln firing of some locally made ceramics occurred. Banded slipware, hand-painted ware, transferware, cut spongeware, and a green decorated Guanajuato majolica sherd, post-1810 in date (Ivey and Fox 1982:39), were recovered in Level 4, along with undecorated whitewares and Goliad ware that is clearly primitive fired. A button fragment of bone, two small chert fragments, and glass container fragments were also recovered.

\section{LEVEL 5}

Level 5 was excavated from 40 to $45 \mathrm{~cm}$ where the deposit became sterile. A modified, somewhat hexagonal sandstone (a probable gaming piece), two undecorated majolica sherds, seven sherds of sandy paste lead-glazed and Indian wares that include both those that may be kiln-fired (based on their even firing) and primitive fired, were recovered. In addition, seven sandy paste lead-glazed sherds, three whiteware sherds (one hand painted), and a small glass container fragment are also attributed to this level. The whiteware sherds were located in areas of intrusive burrow noted in the northeast and southwest corners of the unit. A number of faunal bone specimens were present, including two mandible fragments (one from a small rodent) and an apparent pig tooth. Several chert fragments were found, and charcoal was present, particularly in the western half of Unit 3. This floor is probably late Spanish colonial, or possibly Mexican, in date; its depth relative to the other units suggests a Spanish Colonial date, with the presence of later materials the likely result of intrusive animal burrows. 


\section{ARTIFACT ANALYSIS}

The initial objective in the analysis of the artifacts was to date the deposits exposed during excavations. Temporally diagnostic artifacts, primarily ceramics, were used both to date the strata and to test for their stratigraphic integrity. Historical and archival data, elicited largely from previous studies (Habig 1968; Bolton 1970; Fox and Hester 1976; Ivey, Thurber and Escobedo 1990; Escobedo n.d.), provided an interpretive framework in which to consider the changing use and condition of the southeast section, its changing occupants, and any relevant historical information.

\section{METHODOLOGY}

As the materials were processed, they were sorted into analytical units based on previously established studies (Fox et al, 1989; Uecker, Meskill, and Cox 1991, among others). These groups are, in general, functionally defined (Table 1).

\begin{tabular}{|c|c|c|c|}
\hline Article Type & Total & Article Type & Total \\
\hline Activity Items & 14 & Kitchen/Dining Items & 1934 \\
\hline Amusement & 7 & Ceramics & 420 \\
\hline Sewing & 1 & Glass & 498 \\
\hline \multirow[t]{4}{*}{ Writing } & 6 & Other tableware/kitchenware & 86 \\
\hline & & Faunal Bone & 893 \\
\hline & & Eggshell & 1 \\
\hline & & Mussel Shell & 36 \\
\hline Construction/Architectural Items & 687 & Household Items & 26 \\
\hline Brick/Tile & 168 & Personal/Clothing Items & 24 \\
\hline Decorative (Marine Shell) & 5 & & \\
\hline Utilities & 31 & & \\
\hline Other Construction & & Lithics & 30 \\
\hline Window Glass & 186 & & \\
\hline Plaster/mortar & 21 & Chipped stone & 29 \\
\hline Concrete & 20 & Ground stone & 1 \\
\hline Roofing felt, tar & 72 & & \\
\hline Cut nails & 53 & & \\
\hline Wire nails & 125 & & \\
\hline Tacks, screws, bolt & 6 & & \\
\hline Firearms & 2 & Miscellaneous Items & 29 \\
\hline Percussion cap & 1 & & \\
\hline Pistol shot & 1 & & \\
\hline
\end{tabular}


KITCHEN/DINING ITEMS (1934 specimens)

CERAMICS (420 specimens)

Ceramics were divided into taxonomic units (Table 2). The artifacts then were examined and described. Identifying characteristics and manufacturing techniques are briefly noted within each category's accompanying text.

TABLE 2. CERAMIC SPECIMENS: TYPES AND QUANTITIES

Group 1 Soft Paste Earthenwares - Unglazed

106

Type 1 Goliad Ware - Primitively-Fired

73

Type 2 Goliad Ware - Possibly Kiln-Fired

13

Type 3 Tonalá-Kiln-Fired Burnished Ware

3

Type 4 Unglazed Bisque Ware

8

Type 5 Other Unglazed Ware

Group 2 Soft Paste Earthenwares - Glazed $\quad 66$

Type 1 Lead Glazed 55

Type 2 Tin-Glazed 11

Group 3 Hard Paste Earthenwares - Decorated Whitewares $\quad 90$

Type 1 Transfer 12

Type 2 Hand Painted 39

Type 3 Sponge 16

Type 4 Edge Decorated 5

Type 5 Banded Slip $\quad 18$

Group 4 Hard Paste Earthenwares - Undecorated Whitewares 145

$\begin{array}{ll}\text { Group } 5 \text { Hard Paste Earthenwares - Creamware } & 1\end{array}$

Group 6 Hard Paste Earthenwares - Yellowware 1

$\begin{array}{ll}\text { Group } 7 \text { Stoneware } & 1\end{array}$

\begin{tabular}{ll} 
Group 8 Porcelain & 10 \\
\hline
\end{tabular}

\section{Group 1. Soft Paste Earthenwares - Unglazed}

Soft paste earthenware is fired at relatively low temperatures which are sufficient to fuse the clay, but not to vitrify it (Greer 1981:14-15). Such earthenware is permeable to liquids unless a surface glaze is applied. 


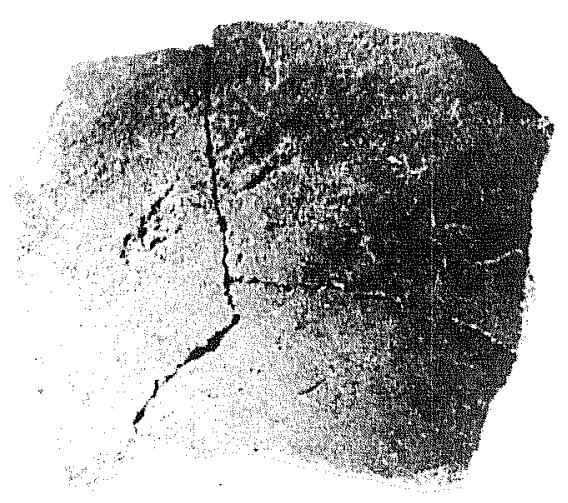

a

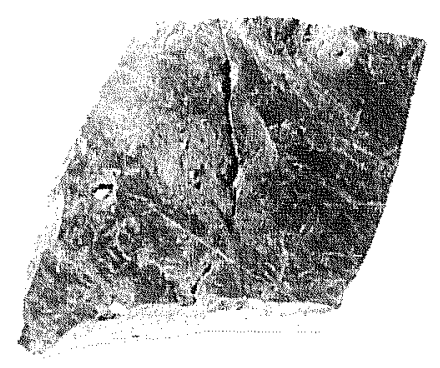

b

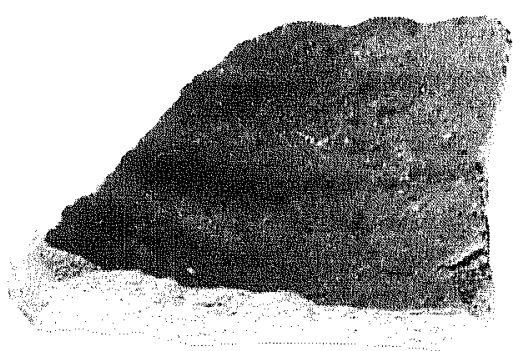

c
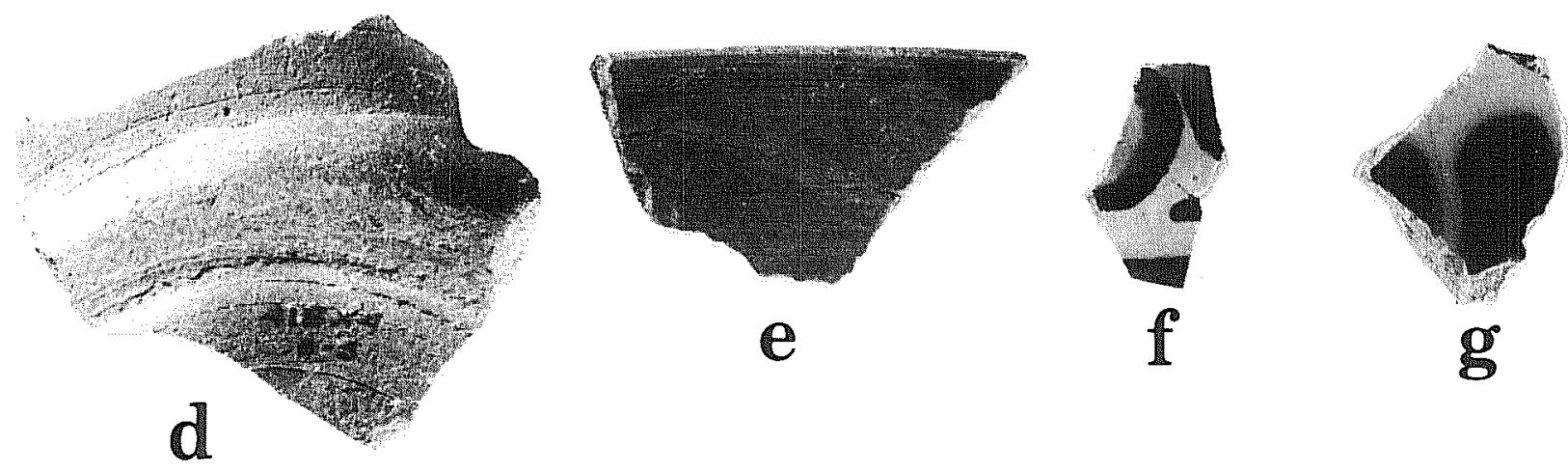

e
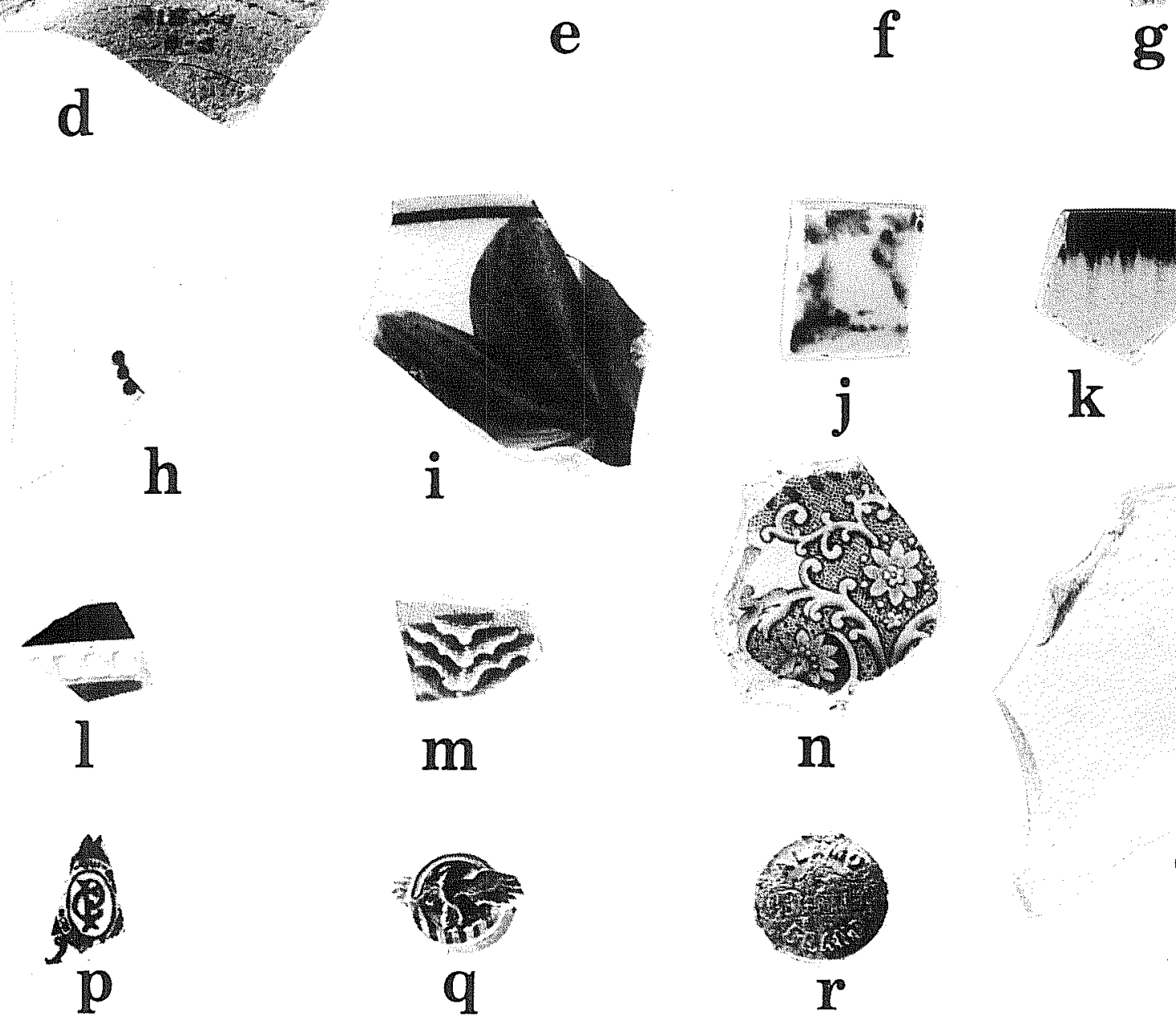
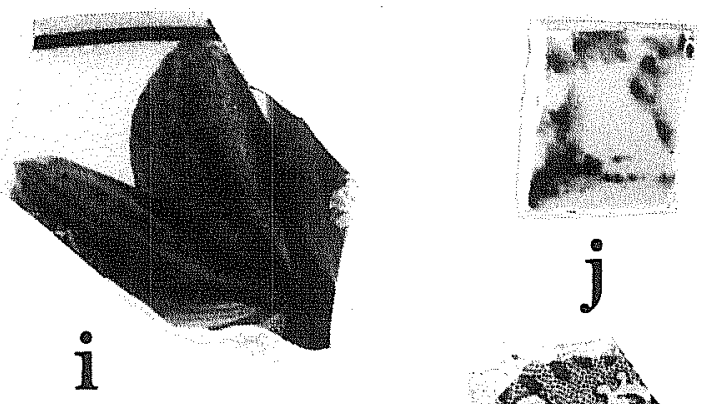

j

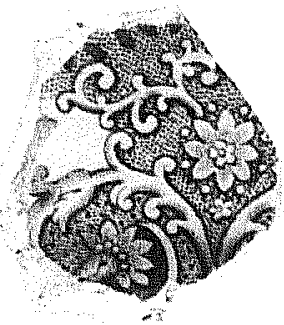

n
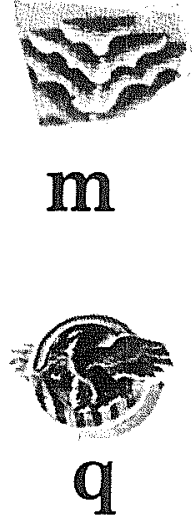

m

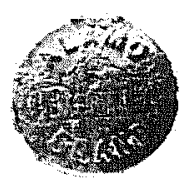

r

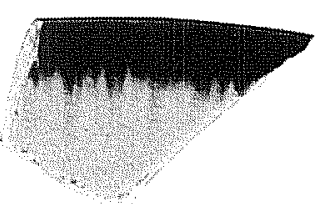

k

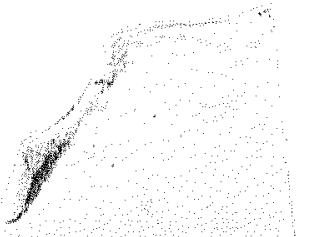

Figure 10. Sample of Artifacts Recovered. a,Goliad; b, Goliad (possibly kiln-fired); c,d, lead glazed (sandy paste); e, lead glazed (green edged); f, San Diego Polychrome; g, Guanajuato; h,i, hand painted; j, cut sponge ware; $k$, edge ware; 1 , banded slip; m,n, transfer ware; o, whiteware; $p$, backstamp; q, "ruptured duck" World Ware II military discharge lapel button; $r$, Alamo Brand button. 
The unglazed soft paste earthenwares group generally consists of pottery of Indian and Hispanic traditions, and includes five categories: primitive fired Goliad wares, Goliad ware that is possibly kiln fired, kiln-fired Tonalá ceramics, unglazed bisqueware (of European tradition), and other unglazed ware.

Indianware comprised approximately one-fifth of the total ceramic inventory collected during the excavations. The presence of Indian neophytes, who inhabited the southeast corner of the compound, likely accounts for the relatively frequent occurrence of this ware.

\section{Type 1. Primitive Fired Goliad Ware (73 specimens;Fig. 10a)}

Type 1 consists of hand-built ceramics that are low fired under primitive conditions. The type is termed Goliad ware based on definition by Mounger of materials excavated from Mission Espiritu Santo excavation. This ware apparently represents a continuing tradition of south Texas Late Prehistoric pottery making. The ceramics, which appear to be bone-tempered, evidence a variety of colorations, apparently due to differential exposure to heat and oxygen during firing and use and/or burning during deposition. One specimen contains a small block of gray clay, having no temper but containing an orange-mottled area of paste, is included within one interesting specimen. Although prehistoric south Texas traditions are usually associated with the jar form (Fox, personal communication), two sherds recovered during these CAR excavations represent the flared rim of a relatively thin-walled, well-made bowl. The bowl shape appears to represent a blend of the Hispanic vessel form with the traditional Indian method of manufacture.

Two of the four other rim sherds included in this category appear to be jar fragments, while the other two are somewhat difficult to diagnose as to vessel form. Goliad ware is frequently found at Historic period sites in the area, and, as noted in Ivey and Fox (1982:39), the pottery continued to be made throughout the Spanish colonial period (1718-1821), perhaps even into the Mexican regime.

\section{Type 2. Goliad Ware - Possibly Kiln Fired (13 specimens; Fig. 10b)}

Some of the Goliad ware assigned to the Type 2 category is of the same construction (including tempering) as that seen in the primitive-fired Type 1 category. The distinguishing factor of these pieces is the evenness of their firing. The paste color is light red $(2.5 \mathrm{YR} 6 / 6)$ or red $(2.5 \mathrm{YR} 5 / 6)$. The consistency of color generally results from firing under the more controlled conditions of the kiln. This even quality contrasts that of the sherds in the previous category, the paste of which is variegated in color, frequently evidencing dark cores. The Indian potters' possible use of the European innovation (the kiln) while simultaneously continuing their traditional fabrication method reflects an interesting acculturative mechanism; this issue is later addressed in the Discussion section. Pottery reflecting the interaction of Indian and Hispanic cultures would likely be Spanish colonial in date. It should be noted that the observed evenness of firing with this category of ceramics could also be the result of post-manufacture exposure to intense heat.

Most of the sherds in this category exhibit burnishing on both the exterior and interior surfaces, although the outer surface is much more evenly smoothed. A number appear to be from the same vessel, probably a jar form.

\section{Type 3. Tonalá - Kiln-Fired, Burnished Wares (3 specimens)}

Only three Tonalá specimens were collected during the excavations. These were yielded from Level 5B within the mottled, compacted surface that appeared to be related to the construction phase of the original wall foundations. The Tonala specimens were evenly fired and thin walled, having a light gray (10 YR 7/1) paste and distinctive red (10 YR 4/4) slipped, burnished exterior. Interior walls have an eroded red slip. The ceramics are part of the long Tonala pottery-making tradition which continues to this day (see Katz 1977); pottery of this type is frequently found at Spanish colonial sites. Although the material from this level is judged to date from, or predate, the original construction of the compound wall, at least one of the 
sherds was collected in the immediate wall area where subsequent reconstruction efforts apparently disturbed the first few centimeters of the level. The sherd could therefore postdate the original mission wall construction.

\section{Type 4. Unglazed Bisque Ware (8 specimens)}

Eight sherds displayed a light gray (2.5 Y 7/2)-to-white (10 YR 8/2) paste, with generally darkened interior surfaces. The morphology of several of these unglazed specimens suggests that they may be fragments of some type of figurine or doll. The bisquewares were recovered from Levels 2,3, and 4 of Unit 1.

Type 5. Other Unglazed Ware (9 specimens)

Nine of the unglazed sherds have a pinkish gray (7.5 YR 7/2; 7.5 YR 6/2) or reddish yellow (5 YR 6/6) paste and are wheel thrown; one has a matte red slip (2.2 YR 5/6). Fox (Ivey and Fox 1981:31) notes that wheel-made pottery which is unglazed and apparently kiln fired is commonly found at 18th-century sites in San Antonio and is referred to as Valero ware. Fox notes that manufacturing of the ware may have occurred in San Antonio. A likely area for the production would have been at the mission sites (note evidence cited in Lead Glazed section). Ivey and Fox (1982:40) associate Valero ware with the middle mission period (1730-1755).

Of the three rim sherds and six body sherds included in this category, one is distinctive for its rim treatments. It has thick walls $(1.0 \mathrm{~cm})$ and a rounded lip with exterior fold.

Group 2. Soft Paste Earthenwares - Glazed (66 specimens)

Type 1. Lead Glazed (55 specimens)

Lead-glazed earthenwares are of Mexican tradition. The pottery was apparently exported in large quantities to the northern borderlands during Spanish colonial times. Lead-glazed wares often comprise a high proportion of the ceramic inventory at mission sites. At San Lorenzo, Tunnel and Newcomb (1969:81), report that the frequency of this type of utility ware suggests that it may have been produced locally, or "quite likely" at a more permanent mission establishment such as those located in San Antonio or south of the border. The lead-glazed pottery is generally wheel thrown. Several of the sherds yielded from the Espada excavations have quite prominent wheel marks indicating that the vessels may have been produced by a potter with novice skills.

The ware would have first been fired to a bisque stage, then removed from the kiln, glazed, and refired (Barnes 1975:3). A temperature of $1000 \mathrm{C}$ to $1150 \mathrm{C}$ is needed in order to mature the glaze (Barnes 1975:5).

During Escobedo's (n.d.) excavations, three kiln cockspurs were found in the southeast corner of the room located north of the bastion, within the east wall of the compound and adjacent to the CAR-UTSA excavations. Cockspurs represent kiln furniture used to separate pottery pieces, particularly glazed ware, when being fired. One of the artifacts evidenced remnants of a green lead glaze on its surface. As Escobedo (n.d.) notes, the finding supports the likelihood of pottery manufacture at the mission involving making lead-glazed products. Schuetz (1969:65), as reported in Escobedo (n.d.), notes the inference of ceramic production based on the recovery of such kiln cockspurs.

Lead-glazed ceramics are divided into categories derived from Fox (1974:55-59). The categories consist of sandy-paste utility ware and fine-textured paste wares with mineral inclusion. 
Sandy-Paste Utility Wares (27 specimens; Fig. 10c,d)

The sandy-paste utility ware includes thick-walled ceramics possessing an orange (Munsell 5 YR 6/4, 5 YR 7/4, 5 YR 7/6) paste and clear-to-greenish glaze. The glaze ingredients are not particularly well ground, and wheel-thrown ridges are sometimes prominent. One sherd has particularly heavy walls and a thick ring base.

Escobedo's (n.d.) finding of kiln cockspurs in the southeast corner, as earlier noted, indicates the possibility that pottery production could have been occurring in association with mission activities. In addition, the remnants of lead glaze on one of the items suggest that such pottery manufacture would probably have included lead-glazed ware. Some of the thicker-walled specimens in the above category may have been produced locally. The paste resembles that seen in the San Jose Mission collection housed at the CAR-UTSA. Petrological studies could clarify the likelihood of localized fabrication through comparisons of the paste composition of the wares with clays from the area.

Fine-textured Paste Wares (27 specimens)

The fine-textured paste wares include three categories: Galera pottery, green-glazed ware, and green-edged ware.

Nineteen of the lead-glazed sherds may be classified as Galera pottery, of probable Mexican origin (Fox 1974:58); similar ware is made in Jalisco today. The pottery is thin-walled, is better fabricated than the sandy paste ware, and has a more finely textured paste body. A nicely applied clear-to-pale-green glaze overlies a pink ( 5 YR 7/4), light reddish brown (5 YR 6/4) or reddish yellow (5 YR 6/6) clay body. Four of the Galera sherds are dichromes, having cream decoration of dots or dark brown linear bands or swirls. Ivey and Fox (1982:40) report that Galera ware makes its appearance late in the middle mission period, dated in Ivey and Fox (1982:47) from 1730 to 1755; it is common in the late mission period, which extends to the 1780 s. Chocolate and bean pots are forms commonly represented by Galera pottery (ibid.).

Three sherds have a distinct olive (5 Y 4/3) glaze applied over a thin-walled, direct-rimmed vessel with a rounded lip. Narrow coil marks evidenced on one of the sherds indicates that slender coils were used in vessel construction. The greener color displayed by these sherds is apparently due to a proportionately higher quantity of copper in the glaze, although exposure to a reducing atmosphere could also be a contributing factor. The sherds were yielded from Levels 5A and 5B of Unit 2.

Five specimens have a rather yellowish paste body with a flowing, dark green glaze decoration applied along the rim only (Fig. 10e). This pottery is relatively thin walled.

\section{Type 2. Tin Glazed (11 specimens)}

Eleven tin-glazed enamelled sherds, fragments of Mexican majolica vessels, were recorded during the excavations (Table 3). Majolicas have a lead-based glaze with added tin, producing a milky, somewhat opaque appearance. The items, imported from Puebla and Mexico City into the northern borderlands (Lister and Lister 1976:118), are frequently found at Spanish colonial sites in the area. Mexican majolicas, with their changing trends in colorations and styles, provide the predominant time diagnostic for Spanish colonial sites.

Majolicas are a product of the Talavera tradition which was brought to the new world by Spanish colonists (May 1972:30). The pottery was soon imitated in New Spain, and resulting Mexican majolicas replaced Spanish imports. Export of the Mexican majolicas to the northern borderlands continued throughout the Spanish 


\begin{tabular}{l|l|l}
\hline \hline \multicolumn{3}{c}{ TABLE 3. CERAMICS: TYPES AND PROVENIENCES } \\
\hline \multicolumn{1}{c}{ Type } & \multicolumn{1}{c}{ Provenience } & Date \\
\hline San Elizario & Unit 2, Level 4 & 1755-1780 (Ivey and Fox 1982:37) \\
San Diego & Unit 2, Level 3 & 1770-1800 (May 1972:35) \\
& Unit 2, Level 4 & \\
Guanajuato & Unit 2, Level 5A (3) & Post-1810 (Ivey and Fox 1982:39) \\
Undecorated & Unit 3, Level 4 & \\
& Unit 2, Level 3 & \\
\hline \hline
\end{tabular}

colonial and Mexican periods but was probably terminated, or at least temporarily truncated, with Texas' independence from Mexico. Goggin, according to Deagan (1987:84), suggests that decorations inspired by the Talavera tradition and by Chinese designs are common on majolica dating to the first half of the 18 th century; after that time, European refined earthenwares influenced the design styles.

The CAR-UTSA investigations yielded a fairly low quantity of majolicas. The majolicas are considered by some researchers to be status related (Goggin 1968), and the concomitant lower status of the occupants of the southeast Espada corner would have probably precluded ready access to the items in this area (Seifert 1977:100).

A small sherd of San Elizario Polychrome was recovered in Level 4 of Unit 2. San Elizario Polychrome is distinguished by the presence of brownish black accents on blue motifs against a milky background. Plates of San Elizario Polychrome type have a single, wide, blue interior rim band (Barnes 1972:10; Ivey and Fox 1982:36) outlined in black and a central design of a bird (usually a long-legged shore bird, according to Deagan [1987:86]) or a deer. Blue dots below the rim band are often decorated with black accents, as is the small fragment collected in Unit 2. Deagan (ibid.) notes that San Elizario dates from about 1750 to 1850.

According to Barnes (1972:30), the influence of European ceramics "flooding" Mexico prior to its independence prompted a shift away from the predominant blue decoration to more colorful polychromes. The resultant Aranama Polychrome tradition, using oranges and greens, is a product of this shift. Motifs are floral and are somewhat cruder in execution than earlier majolicas (Deagan 1987:88). San Diego Polychrome is of the Aranama tradition; black accent lines outline and connect floral patterns and dots of yellow and sometimes light green (May 1972:35-36). It is dated from ca. 1770 to 1800 (ibid.:35), five sherds of this type were excavated from Levels 3, 4 and 5A of Unit 2 (Fig. 10f).

Guanajuato pottery characteristically has a green-tinted enamel and is decorated with aqua green, orange brown or orange and yellow elements with blackish brown accents (Ivey and Fox 1982:39). Although the type usually displays a red paste, the specimen collected from Unit 3, Level 4, has a very pale brown (10 YR 8/3) paste.

Three undecorated, or white, majolica sherds were found. The three sherds may represent fragments of decorated vessels which lack embellishment or may be parts of white vessels. Plain white majolica was made throughout the production continuum.

Group 3. Hard Paste Earthenwares - Decorated Whitewares (90 specimens)

Refined earthenwares, including both decorated and undecorated, constitute over half of the ceramic inventory collected during the Espada excavations. The hard paste earthenwares consist largely of English 
imports, reflecting a European tradition. Large quantities of European ceramics came to the colonies after the 1790 treaty between Spain and England (Barnes 1972:33), swamping the Mexican market prior to Mexican independence in 1821 (ibid.:30). By the early part of the 19th century, the decorative and practical ware was mass produced in England and available at a relatively low cost (Godden 1975:229). Anglo settlers coming into Texas at this time brought English wares with them (Fox 1988:14), and these were present in San Antonio by the early 1830s (Fox 1986:122). It is possible that the items may have entered the Texas area earlier through annual deliveries of goods from central Mexico to the missions.

The Diaz and Casanova families owned the rooms north and west, respectively, of the bastion following secularization of the mission in 1824 (Escobedo n.d.), and the early-19th-century whiteware recovered in the CAR-UTSA investigations may be associated with these families. Father Bouchu assumed ownership of the section in 1902.

Included in the decorated earthenware group are transferware, hand-painted ware, spongeware, edge-decorated ware, and banded slipware. Each class represents underglaze decoration.

\section{Type 1. Transfer (12 specimens)}

To create transferware, oily ceramic pigment is rubbed into copper-engraved designs; the pigment is then transferred onto paper and positioned over an unglazed vessel. After the paper is soaked off, the vessel is lightly fired and then glazed, creating an underglaze design (Godden 1975:228). The process dates as far back as the middle of the 18th century (ibid.). Cobalt blue printed wares and Chinese porcelain designs were popular early on, but by the early part of the 19th century new designs came into fashion (Godden 1975:229).

Twelve transferware sherds were recovered during the Espada excavations (Fig. 10m,n). Five are decorated in cobalt blue, two in a lighter blue, and one each in black, bluish green, purple, mulberry, and red. The easiest color to print (and the least expensive) was one solely of blue (Godden 1975:229). The design on a small black sherd from Unit 1, Level 3, consists of finely etched palm fronds, and is oriental in feeling; it probably dates to the early 19 th century.

Type 2. Hand Painted (39 specimens; Fig. 10h,i)

Hand painted wares were imported through the middle of the 19th century, and the sherds collected at Espada are typical of those generally recovered at early-19th-century sites in the San Antonio area. The predominant designs associated with the hand painted wares are abstract floral motifs, while vessel forms include shallow bowls, saucers, and cups.

Two particularly interesting sherds collected in Levels 3 and 4 of Unit 2 (Fig. 11d,e) were modified into a somewhat circular shape, appearing to be what Schuetz describes as "cuatro" gaming pieces. A hand painted sherd collected from Unit 2, Level 3 is of the same pattern as one of the modified sherd disks. Such items, constructed of sandstone or Goliad or lead-glazed sherds, are often recovered at Spanish colonial sites; the possible gaming pieces are further discussed in the Modified Sandstone Disks section.

Type 3. Cut Sponge (16 specimens; Fig. 10j)

To create cut spongeware, cut-out pieces of natural sponge are dipped in colorant and stamped onto the earthenware at the bisque stage. The pottery, which is found at archaeological sites in the area dating as early as the 1850s (Fox 1988), continued to be made into the 20th century. Its popularity has been recently revived. 

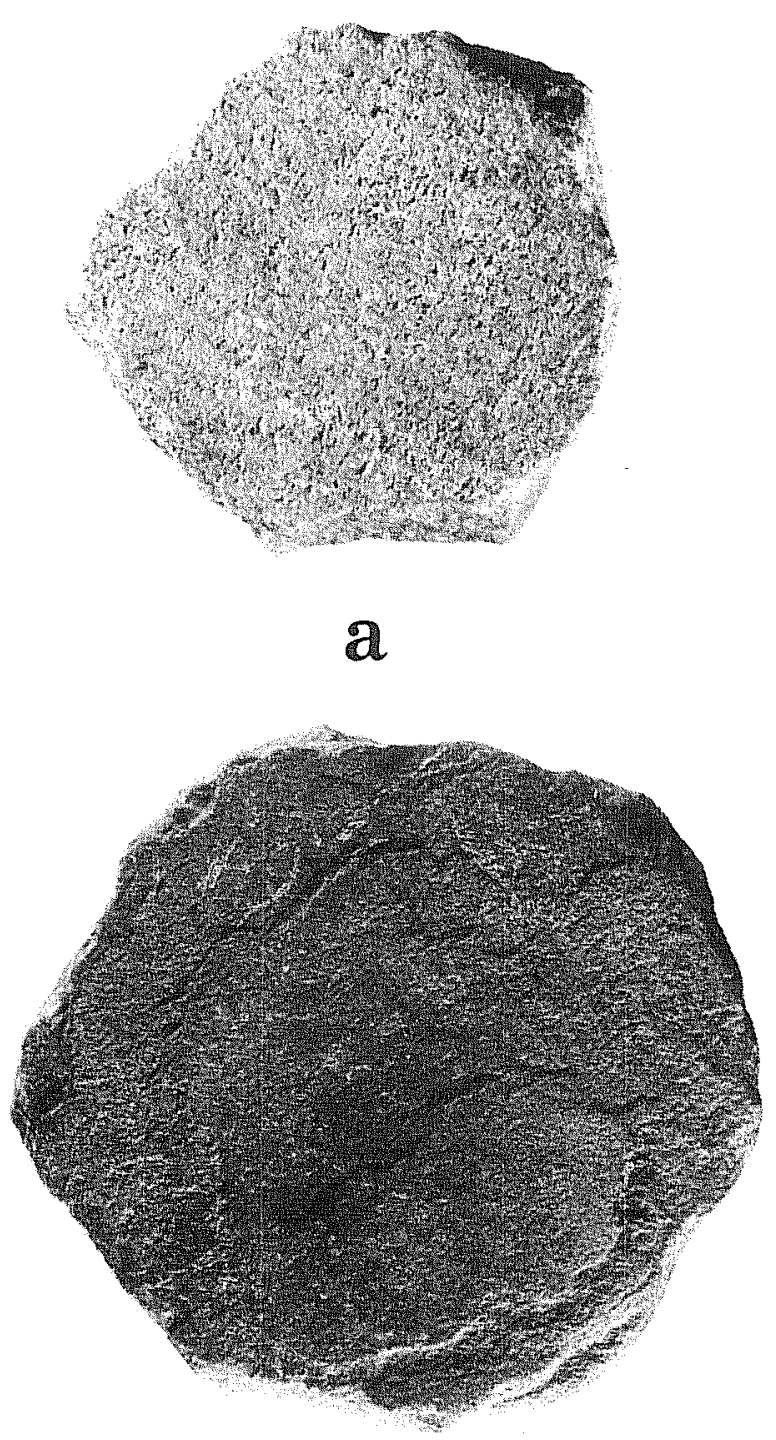

$\mathbb{C}$

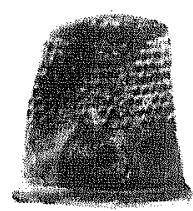

h

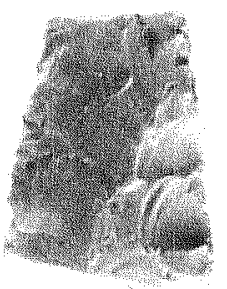

i

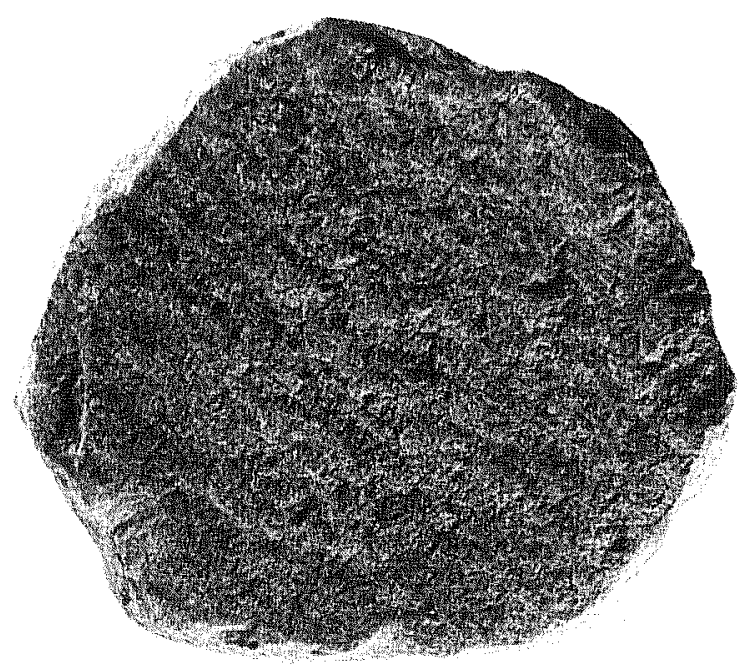

b
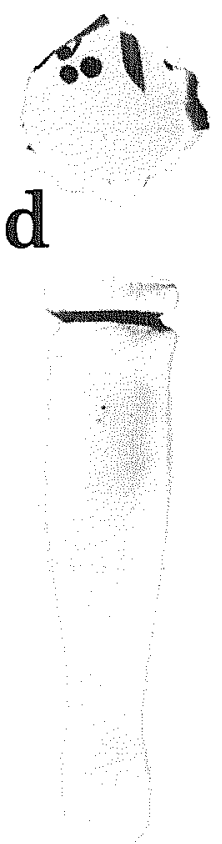

f

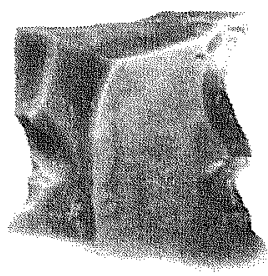

j
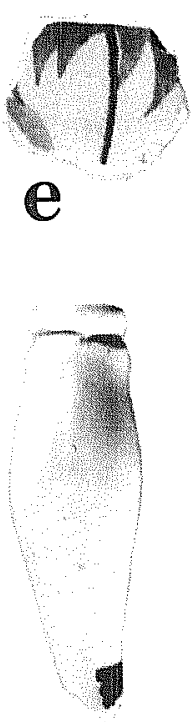

g
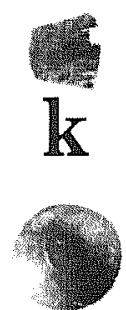

1

Figure 11. Artifacts Recovered during Excavations of 41 BX 4. a-c, modified sandstone disks, d,e, modified ceramic disks; $\mathrm{f}$, doll's arm; $\mathrm{g}$, doll's leg; h, thimble; i, projectile point fragment; $\mathrm{j}$, modified flake; $\mathrm{k}$, percussion cap; 1 , pistol shot. 
Ten cut spongeware specimens are of a rose and/or green color. The five rim sherds, each having a thin-line band below the rim, appear to represent fragments of both shallow bowl and cup forms. Four blue, one purple, and one brown and green sponge-stamped piece are included in the collection.

Type 4. Edge-Decorated (5 specimens; Fig. 10k)

Five specimens display a blue edge decoration; four of these are rim sherds. The rim sherds have non cockled edges and are lightly or poorly incised; Moir's (n.d) chart on edged ware tradition ceramics suggests that they are transitional wares dating ca. 1820-1860.

Type 5. Banded Slip (18 specimens; Fig. 101)

The banded slip form of decoration is produced by dipping the formed vessels into an alkaline slip. According to Godden (1963), Dickens states that the bands were applied with a blow pipe when the jug and mug forms were turned on a lathe. Three of the sherds have an impressed or embossed design at the rim area.

Group 4. Hard Paste Earthenwares - Undecorated Whiteware (145 specimens)

Hard paste earthenware sherds are represented by fragments of undecorated wares or unpainted sections of decorated wares. Two specimens, from Levels 2 and 3 of Unit 2, are enhanced with a fine repoussé treatment along the rim and appear to be from the same vessel (Fig. 10o). Moir (1987:109) dates similar light repoussé patterns ca. 1890-1920. Plain whitewares were prominent during the second half of the 19th century.

Five sherds evidence backstamps. One ironstone sherd from Unit 1, Level 2 has an elaborate, interwoven "CP" within an oval (Fig. 10p), a design which appears to be the mark of the Potter's Co-operative Company, dating from 1882 to ca. 1895 (Gates and Ormerod 1982:212). Another sherd from the same provenience displays a section of the Royal Arms mark and a portion of the word "IRONSTONE."

\section{Group 5. Hard Paste Earthenware - Creamware (1 specimen)}

Unit 2, Level 4 yielded a creamware rim sherd from a thin-walled, straight-sided cup. The "coffee can" shape indicates an early form (Fox, personal communication). Often called "Queensware," the refined, lightweight, cream-colored earthenware was introduced in England by 1740 (Godden 1975:140) and was considered very attractive, even in the undecorated state. According to Godden (ibid.), a stoneware clay was used in the making of creamware that was fired at a moderate temperature.

\section{Group 6. Hard Paste Earthenware - Yellowware (1 specimen)}

The single yellowware sherd is from Unit 2, Level 3. Yellowware is defined by its paste body, the color of which is buff or yellow (Gallo 1985:10). It is lighter in weight than stoneware and is fired at a temperature above $2000 \mathrm{C}$ (ibid.:38). Its history dates to 16th- century or 17th-century England, but yellowware as we know it was produced in England beginning ca. 1780. Productions continued in England, later spreading to the United States and Canada; it lost favor by the 1930s. 
Group 7. Stoneware (1 specimen)

Coarse clays that fuse at a high temperature ( $1200 \mathrm{C}$ to $1300 \mathrm{C}$ or higher) are used to fabricate stoneware (Greer 1981:181). Salt-glazed stonewares, such as the single sherd collected from Unit 3, Level 3, generally predate 1900 .

To create a salt-glazed finish, the salt is introduced into the kiln several times while the vessel is fired, combining with the surface to give a textured (pitted) and glossy finish. The grayed surface of the specimen from Unit 3 is achieved through a more reducing atmosphere (Greer 1981:181). Stoneware is unsuitable for cooking, as its fired body does not expand when heated; it was the preferred ceramic for storage (ibid::16).

Group 8. Porcelain (10 specimens)

Porcelain is made of a fine white clay which is fired to high temperatures of between $1200 \mathrm{C}$ and $1400 \mathrm{C}$ (Greer 1981:15). The porcelain sherds found in Unit 1, Level 2, appear to constitute fragments of a straight-sided cup. A basal fragment located in Unit 3, Level 3, may represent part of a figurine, a small vase, or an egg cup.

\section{GLASS CONTAINERS (498 specimens)}

The container glass category includes 126 clear specimens, 12 black specimens, 86 green items, 158 brown glass fragments, 107 aqua sherds, one blue sherd, and eight white fragments. One mold mark, found on a machine-made brown bottle base, has the marks "1854," "V," " 8 ," and "13."

\section{OTHER TABLEWARE/KITCHENWARE (85 specimens)}

Metal scrap items include 57 pieces of tin scrap, seven iron strap fragments, 11 crown caps, and seven fragments of tin and lead foil. Three metal objects constitute the remaining tableware/kitchenware items. Included with the 85 tableware/kitchenware specimens is an iron pot handle from Unit 1, Level 2, a copper handle fragment from Unit 2, Level 4, and from Unit 1, Level 3, a small delicate metal foot belonging to some type of service item.

\section{FAUNAL BONE (893 specimens)}

Faunal bone predominated the assemblage of artifacts collected during excavations. Bone was most frequent in deposits 20 to $40 \mathrm{~cm}$ deep in each of the units, particularly in Units 1 and 2, directly outside habitation areas. Domesticated animals were prominently represented; cow bone was an important component, along with pig, sheep and/or goat. A probable pig tooth and a tooth from either a goat or a sheep were also recovered. An articulated leg segment (again of sheep or goat) was found in a possible cooking area in Level 4 of Unit 2.

Diane Ballinger, who identified the bone from the Espada collection, relates that identification was problematic due to its fragmented condition; rodent bone was noted in addition to that of domesticated fauna. Burning was prominent on bone found in Level 5 of Unit 1 and was apparent in some of the other levels. Some saw cut bone was found, although breakage resulting from a cleaverlike instrument is more evident with this sample. 
EGGSHELL (1 specimen)

Only one eggshell fragment was found. It is associated with Level 4, Unit 1.

\section{MUSSEL SHELL (36 specimens)}

Dietary evidence is derived from the mussel shell specimens, which include one complete shell, one umbo, and miscellaneous fragments. The shell was found in a number of unit-levels, including strata attributed to Spanish colonial times (Unit 2, Levels 5A and 5B). Utilization of the mussel as a food item during the mission era suggests the Indians' continued reliance (at least in part) on traditional hunting-gathering exploitation.

\section{HOUSEHOLD ITEMS (26 specimens)}

Located at the floor of the first level of Unit 1, was an interesting object - a cast sadiron, lacking its handle, apparently discarded within the rubble level that is associate with the 1932 construction of the school. Light bulb fragments numbered 25; these were recovered from Level 2 of Unit 1 and Level 3 of Unit 2.

\section{PERSONAL AND CLOTHING ITEMS (24 specimens)}

The Personal and clothing items category also includes items of adornment and hygiene. Included in the adornment articles are two beads.

One very small opaque turquoise seed/embroidery bead was found in situ on the Level 4 floor of Unit 2 . It is ring shaped in outline.

A fragment of a tubular bead painted a somewhat iridescent cobalt blue was recovered in Unit 2, Level 3. Microscopic examination revealed rather regularly spaced nicks, or grooves, cut perpendicularly along the length of this piece, which is fragmented in cross section.

The distribution of mission supplies, which arrived annually at Concepción, was reported in Leutenegger's (1976:27) translation of mission guidelines. Similar guidelines were likely operative at the other missions. According to this record, each Indian woman was given a necklace and a basket having three or four strings of beads, depending on the number available. Although the beads were undoubtedly prized items, the women reportedly used them for gambling purposes (ibid.:40).

Other personal items found at Espada include a contemporary watchband fragment from Level 1 of Unit 1 and gold-colored lapel insignia with an eagle found in Unit 2, Level 1. This item, referred to as a "ruptured duck," was issued to honorably discharged World War II veterans (Fig. 10q).

An Alamo Brand overalls stud button with the image of the Alamo on its face (Fig. 10r) was found in Unit 2, Level 4; thirteen additional buttons or button fragments were also recovered, including one green-painted china button, a two-holed shell specimen, and two bone tire-shaped buttons, one from Unit 1 , Level 3, and the other from Unit 3, Level 4. Bone buttons were produced commercially in the early 19 th century (Shepard 1981:83) and are frequently found at area sites of that period; their manufacture continued into the 1920s. While bone buttons were generally used for underwear and trousers, shell buttons were used for fine outerwear and for children's clothing (Luscomb 1967:25).

Also recovered from Unit 1, Level 3, was a brass thimble (Fig. 11h) and the small eye from a hook and eye. Constituting the other clothing items are a large clothing hook (Unit 2, Level 2) and a piece of a decayed possibly feltlike fabric (Unit 1, Level 4). 
Hygiene, or medical, artifacts include a bone-colored molded composition handle with an S-shaped grooved design on one face found in Unit 1, Level 2; the piece perhaps belongs to a vanity item such as a nail file; also found were a comb fragment and a glass tube, appearing to be part of a syringe.

\section{MODIFIED SANDSTONE DISKS (3 specimens)}

Three modified sandstone disks (Fig. 11,a-c), somewhat hexagonal in shape, were recovered; these items, as well as two hand-painted whiteware sherds, exhibit the same shaping. Similarly shaped objects have been repeatedly reported from Spanish colonial sites in the area; Schuetz (1969:74-75) has identified them as "cuatro" gaming pieces. Fox (1992) lists a number of south Texas sites that have yielded like objects: Mission Espiritu Santo (Mounger 1959:246-247, Plate 38); Mission San José (Schuetz 1970:5,9); and the Laredo Toll Bridge site (Folan, et al 1986:31), containing some 48 items dating through the early 20th century. Greer (1967:Fig. 30,b-e) illustrates specimens in sandstone, lead-glazed, and Goliad ware. Fox cites Florida, Arizona, and California as other Spanish colonial areas which have yielded the modified disks.

Interestingly, translations by Leutenegger (1976:40) report that the Indians were avid players of games such as patolli and chueca (a kind of hockey). The former appears to be a reference to the Mixteca, or Aztec, game of patolli, which is similar to the game of Parcheesi (Weaver 1972:258); it was played on a cross-shaped board (which could have been drawn in the dirt) using items, such as marked beans, for tokens. This type of game may have been pan-Mesoamerican. Leutenegger (1976:40) notes that the Indians were so taken with the game "that they would forfeit their blankets, their clothing, and whatever they may have. This is quite common in the mission and the Indians try to hide from the missionary while playing them. The women are different because they do not gamble away their clothing very readily but they do their beads."

The modified sherds and the sandstone disks could be associated with the game of patolli. Although the sandstones may be of a suitable shape to serve as pucks for a hockeylike game, they do not exhibit wear that would suggest such use.

That the somewhat hexagonal shape of some of the Espada specimens may have been achieved with the intention of creating a more rounded form is based on previously published specimens that are "more or less round" (Tunnel and Newcomb 1969:103). The three Espada sandstone disks measure 5.6 to $7.3 \mathrm{~cm}$ in diameter and 1.7 to $2.3 \mathrm{~cm}$ in thickness. This size contrasts that of the small, modified, hand-painted, refined earthenware disks (Fig. 11,d,e) (see Hand-Painted section) which measure a maximum $1.8 \mathrm{~cm}$ in diameter and $0.6 \mathrm{~cm}$ in thickness.

\section{DOLL PARTS (3 specimens)}

A doll's white china arm (Fig. 11,f) was recovered in Level 2 of Unit 1. The mark "1 1/2" can be seen at the top of the arm. A china fragment that appears to represent a portion of hair from a figurine or doll was also found at Level 2. At the next level was located a doll's leg (Fig. 11g), possibly a fragment of the same jointed toy as that from Level 2 . Grooves exhibited at the top of both the arm and leg allowed for attachment (with wire) to a stuffed cloth torso.

Ceramic dolls can be useful time markers at archaeological sites based on clothing, hair, and footwear styles (Prichett and Pastron 1983:321). Although the doll leg is missing the foot/shoe area, it retains what appears to be mastic, or perhaps black paint, on the upper part of the ankle. This suggests the probable presence of a high-top shoe, indicating the piece likely dated from the late 19th century. 


\section{ACTIVITY ITEMS (14 specimens)}

Activity-related artifacts include amusement and sewing items, in addition to writing materials. A brass thimble (Fig. 11,h) was discovered in Level 3 of Unit 1. Pencil leads and an eraser band were also found within the upper three levels of the units. Pastime/amusement items include three modified sandstone disks (probable gaming pieces), three doll parts, and a sounder from a whistle. The sandstone disks and doll parts have been discussed.

\section{LITHICS (30 specimens)}

Lithic, or chert, specimens of chipped stone include one medial fragment of a projectile point (Fig. 11,i) recovered from Level 3 of Unit 1; it is a dart point fragment that measures $3.3 \mathrm{~cm}$ in length, $2.1 \mathrm{~cm}$ in width, and $0.75 \mathrm{~cm}$ in thickness. Although Solis, as reported in Schuetz (1976:41), recorded that arrows were fabricated during mission times by older Indian men, this item represents a dart point, and its presence could be the result of secondary deposition. Hester (1977:10-11) notes that projectile points of a size that would generally be considered dart points are found within mission contexts, and likely represent artifacts from premission era occupations or perhaps curated items. Based on collections from San Bernardo Mission, Hester suggests the possibility that there may be some continuation of "archaic" forms into historic times, with the items functioning as an arrow point, or possibly as a spear tip.

One modified unifacial fragment (perhaps of a blade) is notched along both lateral edges (Fig. 11j), and appears to have been used as a tool; it was recovered from Unit 2, Level 5B, the mottled compacted floor which appears to be associated with the Spanish colonial construction of the mission corner. Recovered in the upper reaches of Unit 2 in Level 2 was a heat-altered primary flake fragment that appears to be modified; Unit 1, Level 4 yielded a biface fragment; seven secondary flakes and 18 miscellaneous tertiary flakes and chips were also found. Fox (1989:48) suggests that the working of chert materials was not abandoned with European contact, but probably continued during the Spanish presence.

A rectangular ground sandstone fragment with a nicely smoothed surface was recovered from Unit 2, Level $5 \mathrm{~A}$, and measures $5.4 \mathrm{~cm}$ in length, $3.1 \mathrm{~cm}$ in width, and $2.1 \mathrm{~cm}$ in thickness. The object appears to have been used as a sharpening stone.

\section{FIREARMS (2 specimens)}

The arms category includes a copper percussion cap and a pistol shot (Fig. 11k,l), both of which were expended. The .44 caliber pistol shot (or "musket ball"), located in Level 4 of Unit 1, exhibits a flattened area of impact. The item is well cast, with no seams apparent or obvious sprue residue extant, although the location of the sprue is quite distinct. The impact area is pronounced. As noted in the Historical Background section, Fannin and Bowie's army took over Mission Espada in the fall of 1835 and staved off an attack by 200 Mexican soldiers at that time. It is possible that the pistol shot and/or the percussion cap could represent remains of such an encounter. The percussion cap was found in Unit 2, Level 3. The size of the small cap $(0.6 \mathrm{~cm}$ in length) is typical of those associated with sporting guns and pistols; rifles utilize a larger style resembling the shape of a "top hat." The small percussion caps, typically of copper, were cut from blanks by machine. Because these caps were difficult to handle due to their small size, they were often dropped, thus slowing the loading process.

Sam Nesmith, (personal communication 1991), identified the ball as a .44 caliber shot; it was either used with a pistol or Kentucky rifle. The item is suitable for either percussion or flint ignition, according to Nesmith, and was likely used by an Anglo rather than a member of the Mexican forces. The percussion cap was probably associated with a pistol rather than a rifle; if used with a pistol, it would have been suited for a .44 . 
Butler (1971:82) reports that percussion arms were introduced in the United States between 1810 and 1820; until 1846, they would have been private property and of the smaller sporting type. The military used percussion arms after that time; military percussion rifles were standard issue by the Civil War.

\section{CONSTRUCTION AND ARCHITECTURAL ITEMS (687 specimens)}

Pieces of unglazed tile (ladrillo) and other construction artifacts, as well as a number of cockleshell fragments, are grouped into one category. The shell is included within this classification as it apparently represents decorative fragments of a cross, on the compound's east wall. This cross was situated above the roof line, overlooking the present excavations.

Uglased Tile (168 specimens)

Ladrillos are tiles or bricks of unglazed coarse earthenware used in the construction of Spanish colonial masonry structures (Deagan 1987:124). Numerous fragments of reddish yellow (5 YR 6/6), yellowish red (5 YR 5/6) or red (2.5 YR 4/6) tile, or ladrillos, were recovered in the excavations; these were found in the majority of the levels in the three units. Notable in Unit 1, the brick-tiles were recovered in the lowest stratum. Manufacture of the tiles is very likely associated with mission activities; Ivey, Thurber, and Escobedo (1990:148) note that the tiles were present in quantity (numbering some 10,000 fired bricks and 300 floor tiles) in the 1772 inventory at Mission Espada. Many can be observed in a ca. 1900 photo (ibid. 369), where they are stacked against the rectory wall behind the noted Espada pastor, Father Bouchu.

The location of a kiln used for firing the bricks has not yet been determined at the mission site, although five kilns for lime processing have been located along the upper terrace of the San Antonio River to the north and east of Espada's compound, just outside the mission walls (Killen and Scurlock n.d.). Fox (personal communication) relates that a kiln could have been constructed of the tiles themselves, the device later dismantled and the tiles used as architectural elements, making it more difficult to determine the kiln's original location. Deagan (1987:124) comments that ladrillos were fabricated by masons rather than by potters.

The brick/tiles are commonly used as decorative elements in Mission Espada architecture. Many currently seen in Espada structures actually derive from use during reconstruction efforts, although some are certainly remains of early construction (as on the arched doorway of the church). A number of the fragments recovered in the excavations exhibit mortar on outer surfaces, indicating previous use, perhaps in the original architecture at the southeast corner. One nearly complete tile associated with Level 4 of Unit 2 is exceptionally large when compared to those generally encountered in area sites (Fox, personal communication). Measuring $25 \mathrm{~cm} \mathrm{x} 20 \mathrm{~cm} \mathrm{x} 4.3 \mathrm{~cm}$, it would probably have served as a floor tile, or was possibly fabricated for a special function.

\section{Marine Shell(5 specimens)}

Cockleshell fragments were recovered in Unit 2, Level 2 and Unit 3, Level 3. Items resembling the four specimens are currently seen as decorative elements on a cross sitting atop the roof on the compound's east wall (Fig.2). A number of the seashells are missing from the cross, and the marine shell fragments recovered during the investigations may represent remnants of those missing members.

\section{Utilities and Other Construction-related Items (483 specimens)}

Electrical wire and ceramic insulator fragments represent the utilities-related items. The six specimens were collected in the upper $30 \mathrm{~cm}$ of Units 1 and 2 . 
Other items include 21 pieces of lime (plaster/mortar) fragments, 67 fragments of roofing felt, five pieces of roofing tar, 20 concrete fragments, and 186 sherds of window glass. Cut nails numbered 53, and 125 wire nails were found. Tacks, screws, and bolts numbered six.

\section{MISCELLANEOUS ITEMS (29 specimens)}

A number of miscellaneous plastic items (bags and other fragments) were recovered. Plastic bags were found in the lowest reaches of the cement foundation area in Unit 1, undoubtedly the result of animal burrowing activity.

\section{DISCUSSION}

The excavations yielded a sequence of materials reflecting the changing occupation dating to Spanish colonial times. Although there was mixing at upper levels, and intrusions were present due both to animal burrowing and the construction and rebuilding of foundations, stratigraphic integrity appeared intact in lower levels outside the obviously disturbed areas, particularly in Unit 2. Temporally diagnostic materials were present in some quantity. The artifact assemblage and the context of the materials were used to date deposits and to determine their nature and stratigraphic integrity.

Cultural evidence associated with a probable preconstruction time frame in Unit 2 offered no convincing evidence for either of the time periods postulated for the southeast corner construction, before 1762 (see Habig 1968:213) or ca. 1780 (Ivey, Thurber, and Escobedo 1990:149). Materials collected beneath the mottled surface in Unit 2, Level 5B (the probable construction surface) included Tonalá and lead-glazed wares but no diagnostic majolicas which would have established a more precise date for the stratum. The artifacts, extending from the latter part of the middle mission period and continuing into the late mission period ca. 1755 to 1780 (Ivey and Fox 1982:46), encompass the span of time for both postulated construction periods.

The changing character of the corner can be reflected in the artifact assemblage collected during the test operations. Based on numerical counts of artifacts for each functionally defined category, construction-related materials predominated the uppermost $10 \mathrm{~cm}$ of each unit, with kitchen items second in frequency ( $35 \%$ of Unit $1,45 \%$ of Unit 2 , and $25 \%$ of Unit 3 ). Personal and household items constituted $1 \%$ or less of the artifacts recovered in the upper $10 \mathrm{~cm}$. The proportion of kitchen-related items increased at the 10 - to $20-\mathrm{cm}$ level within Unit 1 only.

Kitchen/dining artifacts increased significantly within the 20 - to 30 -cm layers (Level 3), representing some 64 to $85 \%$ in each unit; Level 3 represents activity that is more residential in character. The highest ceramic counts are recorded for each unit at Level 3, with undecorated whitewares, the most frequent in quantity, followed by decorated whitewares. Clothing and personal items increased in Level 3 also.

Level 4 was excavated from 30 to $40 \mathrm{~cm}$ in Units 1 and 3, and $30-37 \mathrm{~cm}$ in Unit 2. A surprisingly consistent 85 to $87 \%$ of the artifacts represent kitchen/dining items. Discarded bone was the most frequent artifact. Ceramic counts are somewhat lower than in the previous stratum, and Indian wares number 45 of the 109 sherds; the quantity of whitewares fell noticeably. The materials reflect the corner's use as living quarters and the changing ethnicity of its occupants with evidence of both the Hispanic/European traditions and of the mission age Indian residents being yielded.

Only eight whitewares (including decorated and undecorated) were represented in Level 5 to the lowest reaches of each unit, while Goliad Indian wares, and Tonala, lead-and tin-glazed Spanish colonial ceramics numbered 43. The lower levels were otherwise low in construction materials except for the Spanish colonial brick/tile fragments which totalled 88 . 
Despite the limited scope of the excavations, significant questions regarding socioeconomic issues were considered as analysis was undertaken, including acculturation, cross-cultural exchange, and adaptations to European lifeways. Within the setting of the mission had been enacted a dynamic encounter between the old and new worlds, as the ancient hunting and collecting lifeways of the Indian neophytes were subjected to the drastic changes instigated by missionization. The mission setting provides an ideal laboratory where this change might be observed.

Ivey and Fox (1982:48-49) discussed the issue of culture change in a report on the 1980 excavations at Mission Concepcion. Citing a continuation of Indian lithic and pottery traditions observed in Spanish colonial assemblages, they suggest that a kind of "protective acculturation" may have occurred, with some protohistoric behavior patterns preserved beneath a Hispanic veneer.

Certain observations about the Espada artifact assemblage can be made concerning the Indians' continuation of old lifeways during the process of transformation to the new life style. These considerations are viewed here from the perspective of pottery production and access, and resource exploitation.

The use of traditional primitive-fired ceramics is recorded at Espada as with other Spanish colonial sites of the area. Some sherds of very evenly fired Goliad type ware suggest the possibility of having been kiln baked, an adaptation of the European method of firing. Access to the kiln would be a factor here. Concerning vessel form, the use of a bowl shape with flared rim on otherwise diagnostic Goliad ware reflects a selective borrowing of Hispanic culture traditions.

Escobedo's (n.d.) finding of kiln furniture during excavations within the walls of the southeast corner rooms indicates that lead-glazed pottery was probably manufactured at the mission. This would account for the somewhat crudely fashioned wheel-turned pottery which is sometimes retrieved at Spanish colonial sites in the area and appears to result from novice attempts at achieving a facility with the wheel. Controlled access to the "new" wheel-thrown kiln-fired pottery of Hispanic tradition, however, could have been a factor in the continuing use of the "old," as the mission authorities may have distributed the innovative items to the Indian neophytes in controlled quantities.

Although the use of domesticated animals was probably adopted quickly by the missionized Indians, the finding of mussel shell and bone from undomesticated fauna suggests at least a partial retention of hunting and gathering cultural patterns.

Given the limited scope of the investigations, the number of gaming pieces (five) is somewhat surprising. The relative frequency attests to the popularity of pastime activity; whether the games represented are of Hispanic or Indian origin is not known, although the games of patolli, noted in Leutenegger (1976:40), is apparently of Mesoamerican origin (Weaver 1972:258).

South (1979:213-237) has defined three zones of refuse disposal (i.e., primary midden, secondary midden, and peripheral zones) dealing with meat disposal in circumscribed spaces; the Espada compound would be an excellent example of such a space. The pattern observed in the lower levels of Espada suggests that the remains may have been simply tossed out adjacent to the entrances, and that these areas represent primary midden contexts. A cooking locus is also suggested in the southeast section of Level 4 in Unit 2.

\section{SUMMARY AND CONCLUSIONS}

The testing operations revealed that 20th-century concrete foundations were in place under the east wall of the plaza at Unit 1, where a 1932 school had been constructed. With the possible exception of several isolated rocks seen beneath the concrete foundation, the original mission era footings were not identified in Unit 1. 
Intact Spanish colonial foundations, constructed of unmodified stones, were exposed at Unit 2 under the south wall of the plaza. A compacted white-flecked surface found at the base of Level $5 \mathrm{~A}$ (38 to $41 \mathrm{~cm}$ in depth) appears to be the ground surface related to mission era construction. A slight mounding of the surface adjacent to the wall at the $38-\mathrm{cm}$ depth, along with a patch of sand and caliche recorded in the profile cut (Fig. 8), suggests that the actual ground surface at the time of construction of the southeast corner compound may be better represented at the 41-cm depth. The probable edge of the footing trench for the foundation was detected $20 \mathrm{~cm}$ north of the wall.

The character of the foundations found in Unit 2, constructed of unmodified stones and attributed to the mission period, differs from the sandstone footings revealed at the exterior of the bastion during excavations by Fox and Hester (1976). The Fox and Hester (ibid.:14) study reported that the juncture of bastion and compound wall, exhibited a difference in the depth of the footings between west room and bastion; this supported separate construction of the defensive feature. The differing nature of the foundations exposed in the current investigations support the proposal by Fox and Hester that the bastion may have been built independently of the remainder of the compound's southeast corner.

Units 1 and 2 appeared to be devoid of cultural materials below 45 and $43 \mathrm{~cm}$, respectively, except for disturbed areas. The depths recorded here are apparently associated with the mission's original occupation, prior to the building of stone quarters in the southeast corner of the compound.

The suggestion of a wall alignment first noted in Level 2 of Unit 3 excavations, and indicated on a photograph found within the Catholic Archives (Kreck collection), are apparent remnants of a low-lying wall that lie north to south parallel to the east wall of the compound. Remains of the wall alignment are expected to be encountered beginning some $10 \mathrm{~cm}$ or more below the surface. This should be considered if modifications occur in the area where the wall is indicated in the photograph and in Figure 11.

\section{RECOMMENDATIONS}

Results from test operations conducted by CAR-UTSA reveal that there is no need for additional investigations at this time. However, the following objectives are strongly advocated:

(1) Modification to a limited depth, if possible less than five inches;

(2) On-site monitoring as modifications are in process.

The presence of intact cultural remains is clearly documented through the CAR-UTSA testing. Artifactual materials will undoubtedly be encountered with subsurface disturbance. Also, structural activity (sometimes quite ephemeral in nature) is often recorded within mission courtyards, and this possibility must be taken into account during modifications.

Intact mission era strata were documented with the testing, although disturbance at walls and by rodent activity was noted. Occasional flagstones were exposed in Unit 2 at a depth of about $26 \mathrm{~cm}$, continuing to a depth of approximately $37 \mathrm{~cm}$; it is possible that these represent remnants of a flagstone surface, or flooring, for the plaza.

Mission era foundations are in place at the south wall to a depth of almost $90 \mathrm{~cm}$, as attested to by Unit 2 excavations. These foundations are likely extant along the east wall at the southern end of the plaza, extending perhaps to the northern end of the room north of the bastion. Architectural plans on file at the Catholic Archives of the San Antonio Archdioceses record the 1930s school construction to the north and east of this room. The concrete foundation for the 1930s construction was exposed at the east wall in Unit 1 , situated just north of the door to the park ranger's office. 
A percussion cap and pistol shot found in the testing within Levels 3 and $4(20-40 \mathrm{~cm})$ of Units 1 and 2 suggest possible remains of an encounter documented between Mexican soldiers and the Texan army under Fannin and Bowie. The possibility of further evidence of this encounter should be heeded.

A loose stone alignment found in Unit 3 (in the central area of the plaza's corner, $8 \mathrm{~m}$ away from south and east walls) may be remains of a low-lying wall recorded in the 1930s photograph in the Catholic Archives. Further remains of such a feature may be found with subsurface disturbance relative to land modifications. The upper reaches of Unit 3, it might be added, appear somewhat more disturbed than the other two test units.

\section{REFERENCES CITED}

Barnes, M.

1972 Majolica of the Santa Cruz Valley, Arizona. In Mexican Majolica in Northern New Spain, co-edited with R. May. Pacific Coast Archaeological Society Occasional Papers 2:1-24.

1975 Mexican Lead Glazed Earthenwares. Manuscript on file, Center for Archaeological Research, The University of Texas at San Antonio.

Bolton, H. E.

1970 Texas in the Middle Eighteenth Century. Reprint edition of 1915 publication. University of Texas Press, Austin.

Butler, D.

1971 United States Firearms: The First Century 1776-1875. Winchester Press, New York.

Castañeda, C. E.

1937 A Report on the Spanish Archives. Yanaguana Society Publications, San Antonio.

Deagan, $\mathrm{K}$.

1987 Artifacts of the Spanish Colonies of Florida and the Caribbean, 1500-1800. Vol. 1. Ceramics, Glassware, and Beads, Smithsonian Institution.

Escobedo, S.

n.d. Untitled report on 1984 excavations at Mission Espada. Copy on file at the Center for Archaeological Research, The University of Texas at San Antonio.

Folan, W.J., W. Cox, A. Fox, and G. Hinojosa

1986 Laredo, Texas: Gateway Community on the Texas Borderlands, Archaeological and Historical Investigations for the Laredo City Toll Plaza. Center for Archaeological Research, The University of Texas at San Antonio, Archaeological Survey Report 116. 
Fox, A. A.

1974 Lead Glazed Wares. In Mission Rosario, Archaeological Investigations in 1973, by K. Gilmore. Texas Parks and Wildlife Department, Parks Division, Historic Sites and Restoration Branch, Archaeological Report 14.

1981 Test Excavations at Mission San Francisco de la Espada. Center for Archaeological Research, The University of Texas at San Antonio, Archaeological Survey Report 108.

1986 Ceramics. In La Villita Earthworks (41 BX 677): San Antonio, Texas. A Preliminary Report of Investigations of Mexican Siege Works at the Battle of the Alamo, assembled by J.H. Labadie:107-127. Center for Archaeological Research, The University of Texas at San Antonio, Archaeological Survey Report 159.

1988 Archaeological Investigations at Mission Concepción, Fall of 1986. Center for Archaeological Research, The University of Texas at San Antonio, Archaeological Survey Report 172.

1989 The Indians at Rancho de las Cabras. In Columbian Consequences Vol. 1 Archaeological and Historical Perspectives on the Spanish Borderlands West, edited by D.H. Thomas: 259-267. Smithsonian.

1992 Archaeological Investigations in Alamo Plaza, 1988 and 1989. Center for Archaeological Research, The University of Texas at San Antonio, Archaeological Survey Report 205.

Fox, A. A. and T. R. Hester

1976 Archaeological Test Excavations at Mission San Francisco de la Espada. Center for Archaeological Research, The University of Texas at San Antonio, Archaeological Survey Report 22.

Gallo, J.

1985 Nineteenth and Twentieth Century Yellow Ware. Heritage Press, Richfield Springs, New York.

Gates, W. C., Jr., and D. E. Ormerod

1982 The East Liverpool Pottery District: Identification of Manufacturers and Marks. Historical Archaeology 16.

Godden, G. A.

1963 British Pottery and Porcelain, 1780-1850. A.S. Barnes and Company, Inc., Cranbury, New Jersey.

1975 British Pottery, An Illustrated Guide. Clarkson N. Potter, Inc., New York.

Goggin, J. M.

1968 Spanish Majolica in the New World, Types of the Sixteenth to Eighteenth Centuries. Department of Anthropology, Yale University, Yale Publications in Anthropology 72. 
Greer, G. H.

1981 American Stonewares. Schiffer Publishing Limited., Exon, Pennsylvania.

Greer, J.

1967 A Description of the Stratigraphy, Features and Artifacts from an Archaeological Excavation at the Alamo. State Building Commission Archaeological Program Report 3.

Guerra, M. A. N.

1982 The Missions of San Antonio. Alamo Press, San Antonio.

Habig, M. A.

1968 The Alamo Chain of Missions, A History of San Antonio's Five Old Missions. Francisan Herald Press, Chicago, Illinois.

Hester, T. R.

1977 The Lithic Technology of Mission Indians in Texas and Northeastern Mexico. Lithic Technology 63:9-12.

Ivey, J. E.

1983 Archaeological Testing at Rancho de las Cabras, Wilson County, Texas. Second Season. Center for Archaeological Research, The University of Texas at San Antonio, Archaeological Survey Report 121.

Ivey, J. E. and A. A. Fox

1981 Archaeological Survey and Testing at Rancho de las Cabras, Wilson County, Texas. Center for Archaeological Research, The University of Texas at San Antonio, Archaeological Survey Report 104.

1982 Artifact Analysis. In Archaeological Investigations at Mission Concepción and Mission Parkway. Center for Archaeological Research, The University of Texas at San Antonio, Archaeological Survey Report 114. Manuscript on file.

Ivey, J. E., M. B. Thurber, and S. Escobedo

1990 Of Various Magnificence: The Architectural History of the San Antonio Missions in the Colonial Period and the Nineteenth Century. National Park Service Southwest Regional Office, Southwest Cultural Resources Center, Professional Papers II. Santa Fe, New Mexico. Copy on file at San Antonio Missions National Historical Park.

Jones, C. J. and A. A. Fox

1983 Archaeological Testing at Rancho de las Cabras, Wilson County, Texas. Third Season. Center for Archaeological Research, The University of Texas at San Antonio, Archaeological Survey Report 123. 
Katz, R. R.

1977 The Potters and Pottery of Tonalá, Jalisco, Mexico: A Study in Aesthetic Anthropology. Ph.D. dissertation, Columbia University.

Killen, K. and D. Scurlock

n.d. A Report on Preliminary Test Excavations at Mission Espada Kilns, San Antonio, Texas. Preliminary Draft. Manuscript on file, Texas Historical Commission, Austin, Texas.

Leutenegger, B., translator

1976 Guidelines for a Texas Mission: Instructions for the Missionary of Mission Concepcion in San Antonio (ca. 1760). Old Spanish Missions Historical Research Library, Mission San José, San Antonio.

Lister, F. C. and R. H. Lister

1976 Distribution of Mexican Majolica along the Northern Borderlands. In Collected Papers in Honor of Marjorie Ferguson Lambert. Papers of the Archaeological Society of New Mexico 3:113-140.

Lorraine, D.

1968 An Archaeologist's Guide to Nineteenth Century American Glass. Historical Archaeology 2:35-44.

Luscomb, S. C.

1967 The Collector's Encyclopedia of Buttons, Bonanza, New York.

May, R.

1972 An Evaluation of Mexican Majolica in Alta California Employing Preliminary Data from the San Diego Presidio. In Mexican Majolica in Northern New Spain, coedited with M. Barnes. Pacific Coast Archaeological Society Occasional Papers 2:15-50. San Diego.

Moir, R. W.

1987 Refined Earthenwares and Rural Ceramic Traditions. In Historic Buildings, Material Culture, and People of the Prairie Margin. Archaeology Research Program, Southern Methodist University, Richland Creek Technical Series, Vol. 5.

n.d. Shell-Edged Wares Ceramic Tradition, ca. 1775 to 1900 . Unpublished chart, copy on file, Center for Archaeological Research, The University of Texas at San Antonio.

Munsell Color

1975 Munsell Soil Color Charts. Macbeth Division of Kollmorgen Corporation, Baltimore, Maryland. 
Mounger, M. A.

1959 Mission Espiritu Santo of Coastal Texas: An Example of Historic Site Archaeology. Masters Thesis, the University of Texas at Austin.

Porrua Turanzas, J., editor

1961 Documentos Para la Historia Eclesiastica Civil de la Provincia de Texas or Nuevas Philipinas, 1720-1779. Coleción Chilmalistic de Libros y Documentos Acerca de la Nueva España 12, Madrid, Spain.

Prichett, J. and A. Pastron

1983 Ceramic Dolls as Chronological Indicators: Implications from a San Francisco Dump Site. In Forgotten Places and Things, Archaeological Perspectives on American History, edited by A. E. Ward. Center for Anthropological Studies, Albuquerque, New Mexico.

Schuetz, M.

1969 The History and Archaeology of Mission San Juan Capistraño, San Antonio, Texas. Vol. II. State Building Commission Archaeological Program Report 11. Austin.

1970 Archaeological Investigations at Mission San José in April 1968. Texas Historical Survey Committee Archaeological Report 19. Austin.

1976 Indians of the San Antonio Area. In San Antonio in the Eighteenth Century, edited and published by the San Antonio Bicentennial Heritage Committee, San Antonio, Texas.

Seifert, D.J.

1977 Archaological Majolicas of the Rural Teotihuacan Valley, Mexico. PhD. Dissertation, The University of Iowa.

Shepard, S. J.

1981 Nails, Buttons, Tobacco Pipes, and Dolls: Remnants of Historic Occupation. In $A$ Guide for Historical Archaeology in Illinois, edited by C.E. Orser: 78-99. Loyola University of Chicago.

Smith, H. P., Jr.

1980a Espada Mission, Research and Restoration. La Tierra 7(2):3-18.

1980b Developmental Phases at Mission San Francisco de la Espada. La Tierra 7(4):36-39.

South, S.

1979 Historic Site Content, Structure, and Function. American Antiquity 44:213-237. 
Taylor, A. J. and A. A. Fox

1985 Archaeological Survey and Testing at Rancho de las Cabras, 41 WN 30, Wilson County, Texas, Fifth Season. Center for Archaeological Research, The University of Texas at San Antonio, Archaeological Survey Report 144.

Tunnell, C. and W. W. Newcomb, Jr.

1969 A Lipan Apache Mission, San Lorenzo de la Santa Cruz, 1762-1771. Bulletin of the Texas Memorial Museum 14.

Uecker, H. G., F. K. Meskill, and I. W. Cox

1991 Archaeological Investigations at the Ruiz Family Property (41 BX 795), San Antonio, Texas. Center for Archaeological Research, The University of Texas at San Antonio, Archaeological Survey Report 198.

Weaver, M. P.

1972 The Aztecs, Maya, and Their Predecessors. Seminar Press, New York.

Winfrey, D. H.

1965 San Francisco de Espada. In Six Missions of Texas. Texian Press, Waco. 